TRADE AND GROWTH: AN

EMPIRICAL INVESTIGATION

Jeffrey A. Frankel

David Romer

Working Paper 5476

NATIONAL BUREAU OF ECONOMIC RESEARCH

1050 Massachusetts Avenue

Cambridge, MA 02138

March 1996

We are grateful to Susanto Basu, Michael Dotsey, N. Gregory Mankiw, Glenn Rudebusch, James Stock, Shangin Wei, and Richard Zeckhauser for helpful comments, to Teresa Cyrus for outstanding research assistance and helpful comments, and to the National Science Foundation for financial support. This paper is part of NBER's research programs in Economic Fluctuations and Growth, and International Finance and Macroeconomics. Any opinions expressed are those of the authors and not those of the National Bureau of Economic Research.

(C) 1996 by Jeffrey A. Frankel and David Romer. All rights reserved. Short sections of text, not to exceed two paragraphs, may be quoted without explicit permission provided that full credit, including $(\mathcal{O}$ notice, is given to the source. 


\title{
TRADE AND GROWTH: AN EMPIRICAL INVESTIGATION
}

\begin{abstract}
Countries' geographic characteristics have important effects on their trade, and are plausibly uncorrelated with other determinants of their incomes. This paper therefore constructs measures of the geographic component of countries' trade and uses those measures to obtain instrumental variables estimates of the effect of trade on income. The results suggest that ordinary least squares estimates understate the effects of trade, and that trade has a quantitatively large, significant, and robust positive effect on income.
\end{abstract}

Jeffrey A. Frankel

Department of Economics

University of California, Berkeley

Berkeley, CA 94720

and NBER
David Romer

Department of Economics

University of California, Berkeley

Berkeley, CA 94720

and NBER 


\section{INTRODUCTION}

This paper is an empirical investigation of the impact of international trade on standards of living. From Adam Smith's discussion of specialization and the extent of the market, to the debates about import substitution versus export-led growth, to recent work on increasing returns and endogenous technological progress, economists interested in the determination of standards of living have also been interested in trade. But despite the great effort that has been devoted to studying the issue, there is little persuasive evidence concerning the effect of trade on income.

To see the basic difficulty in trying to estimate trade's impact on income, consider a cross-country regression of income per person on the ratio of exports or imports to GDP (and other variables). Such regressions typically find a moderate positive relationship. ' But this relationship may not reflect an effect of trade on income. As Helpman (1988), Bradford and Chakwin (1993), Rodrik (1994), and others observe, countries whose

1 See, for example, Michaely (1977), Feder (1983), Kormendi and Meguire (1985), Quah and Rauch (1990), Fischer (1991, 1993), Dollar (1992), Levine and Renelt (1992), Edwards (1993a), Harrison (1995), and the ordinary least squares regressions in section III of this paper. Edwards (1993b) and Rodrik (1993) survey the literature. 
incomes are high for reasons other than trade may trade more.

Using measures of countries' trade policies in place of (or as an instrument for) the trade share in the regression does not solve the problem. ${ }^{2}$ countries that adopt free-market trade policies may also adopt free-market domestic policies and stable fiscal and monetary policies. Since these policies are also likely to affect income, countries' trade policies are likely to be correlated with factors that are omitted from the income equation. Thus they cannot be used to identify the impact of trade (see, for example, Sala-i-Martin, 1991).

This paper proposes an alternative instrument for trade. As the literature on the gravity model of trade demonstrates, geography is a powerful determinant of bilateral trade. ${ }^{3}$ And as we show in this paper, the same is true for countries' overall trade: simply knowing how far a country is from other countries provides considerable information about the amount that it trades. For example, the fact that New Zealand is far from most other countries reduces its trade; the fact that Belgium is close to many of the world's most populous countries increases its trade.

Equally important, the component of trade that is due to geographic considerations is unlikely to be correlated with other

2 For examples of this approach, see Fischer (1991, 1993), De Long and Summers (1991), Lee (1993), Dollar (1992), Edwards (1993a), Easterly (1993), and Harrison (1995).

3 A seminal reference on the gravity model is Linneman (1966). Deardorff (1984) provides a general discussion of the model. Frankel, stein, and Wei (1995) and Frankel (1996) discuss microeconomic foundations of the model, provide estimates using recent data, and give further references. 
factors that affect income. That is, it is difficult to think of reasons that, for example, geographic isolation can affect a country's income other than by reducing its interactions with other countries. Thus, the geographic component of trade provides a legitimate instrument for overall trade in the crosscountry regression.

In short, the basic goal of this paper is to estimate a cross-country regression of income on trade and other variables, instrumenting for trade using geographic variables. The remainder of the paper therefore consists of two main sections. The first uses geographic variables to construct the instruments, and the second uses the instruments to examine the relationship between trade and income. ${ }^{4}$

We construct the instruments for trade using two approaches. In both, we first estimate a bilateral trade equation and then aggregate the fitted values of the equation to estimate a geographic component of countries' overall trade. Where the two approaches differ is in the variables included in the bilateral trade equation. In the first, which we refer to as the "pure geography" approach, we consider only variables that are entirely geographic: countries' sizes, their distances from one another,

4 Lee (1993) also uses information on countries' distances from one another to construct a measure of their propensity to trade. His approach differs from ours in two major respects. First, his measure is based not only on countries' geographic characteristics, but also on their actual trade patterns; thus it is potentially correlated with other determinants of income. second, he does not investigate the relationship between income and his measure of the propensity to trade, but only the relationship between income and the interaction of $h$ is measure with indicators of distortionary trade policies. 
whether they border one another, and whether they are landlocked.

As the literature on the gravity model emphasizes, the incomes of a country's trading partners are a major determinant of its bilateral trade patterns. Yet the pure geography approach does not use any information about partners' incomes. As a result, the measures of trade constructed using this approach are only moderately correlated with actual trade. Our second approach, which we call the "factor accumulation" approach, therefore uses some information about partners' incomes in addition to the geographic variables. We do not use partners' incomes directly, because they are likely to be correlated with omitted variables in the cross-country income regression that we ultimately want to estimate. Instead, we employ measures of partners' capital accumulation and population growth, which are important determinants of their incomes. We argue below that these variables are likely to be uncorrelated with omitted variables in the income regression, and can therefore be used in constructing the instrument for trade. The key to the argument is that the relation between these measures and income is similar to the predictions of a model where factor accumulation is uncorrelated with other variables affecting income.

We then employ the instruments to investigate the impact of trade on income. We estimate cross-country regressions of income per person on openness and other factors by instrumental variables (IV), and compare the results with ordinary least squares (OLS) estimates of the same equations. There are three main findings. First, we find no evidence that the positive 
association between trade and income arises because countries whose incomes are high for other reasons engage in more trade. on the contrary, in almost every specification we consider, the IV estimate of the effect of trade is larger than the oLS estimate, often by a considerable margin. Second, the point estimates suggest that the impact of trade is substantial. In a typical specification, the estimates imply that increasing the shares of both exports and imports in GDP by one percentage point raises income per person by two percent or more. And third, the impact of trade on income is not estimated very precisely. As a result, although the null hypothesis that trade has no effect is typically rejected at conventional levels, the estimates still leave considerable uncertainty about the magnitude of the effect.

\section{CONSTRUCTING THE INSTRUMENTS}

our ultimate goal is to estimate an equation of the form

$$
\ln Y_{i}=\alpha+\beta \tau_{i}+\gamma^{\prime} Z_{i}+\varepsilon_{i}
$$

Here $\mathrm{Y}$ is income per person; $\tau$ is a measure of openness; $Z$ is a vector of other variables, such as factor endowments, that may affect income; and $i$ indexes countries. The purpose of this section is to construct instruments for $\tau$.

our measure of $\tau$ is a country's total trade (exports plus imports) divided by its GDP. By definition, $\tau_{i}$ is the sum of 
country i's bilateral trade with each other country in the world as a share of i's GDP. That is, $\tau_{i} \equiv \Sigma_{j \neq i}\left(T_{i j} / G D P_{i}\right)$, where $T_{i j}$ is bilateral trade between countries $i$ and $j$ (again measured as exports plus imports). Our basic strategy is therefore to begin with an equation for $T_{i j} / G D P_{i}$ as a function of the distance between countries, their sizes, and so on. We use the estimated equation to find a fitted value of $T_{i j} / G D P_{i}$, and then aggregate over $j$ to find a geographic component of $\tau_{i}$.

As described in the introduction, we implement this idea in two ways. The remainder of this section describes the specifics of the two approaches.

\section{A. THE PURE GEOGRAPHY APPROACH}

The Bilateral Trade Equation. Work on the gravity model of bilateral trade shows that trade between two countries is negatively related to the distance between them and positively related to their sizes, and that a log-linear specification characterizes the data fairly well. Thus a minimal specification of the bilateral trade equation is

$$
\ln \left(T_{i j} / G D P_{i}\right)=a_{0}+a_{1} \ln D_{i j}+a_{2} \ln s_{i}+a_{3} \ln s_{j}+e_{i j},
$$

where $D_{i j}$ is the distance between $i$ and $j$ and $s_{i}$ and $s_{j}$ are measures of the countries' sizes.

This specification omits a considerable amount of geographic information about trade. The actual equation that we estimate 
therefore differs from (2) in three ways. First, we include two measures of size, population and area (both in logs). Second, whether countries are landlocked and (especially) whether they have a common border with one another have large effects on trade; we therefore include dummy variables for these factors. And third, a large part of countries' trade is with their immediate neighbors. Since our goal is to identify geographic influences on overall trade, we therefore include interaction terms of all of the variables with the common-border dummy.

The fact that we are measuring trade relative to country i's GDP means that we are already including a measure of country i's size. We therefore do not constrain the coefficients on the population measures for the two countries, or the coefficients on the area measures, to be equal. We do, however, constrain the coefficients on the landlocked dummies, and their interactions with the common-border dummy, to be equal for $i$ and $j .5$ Thus, the equation we estimate is

$$
\begin{aligned}
\ln \left(T_{i j} / G D P_{i}\right)=a_{0} & +a_{1} \ln D_{i j}+a_{2} \ln P_{i}+a_{3} \ln A_{i}+a_{4} \ln P_{j} \\
& +a_{5} \ln A_{j}+a_{6}\left(L_{i}+L_{j}\right)+a_{7} B_{i j}+a_{8} B_{i j} \ln D_{i j} \\
& +a_{9} B_{i j} \ln P_{i}+a_{10} B_{i j} \ln A_{i}+a_{11} B_{i j} \ln P_{j} \\
& +a_{12} B_{i j} \ln A_{j}+a_{13} B_{i j}\left(L_{i}+L_{j}\right)+e_{i j},
\end{aligned}
$$

where $P$ is population, $A$ is area, $L$ is a dummy for landlocked 5 Allow
trivially.

5 Allowing them to differ changes the results only 
countries, and $\mathrm{B}$ is a dummy for a common border between two countries.

Data and Results. We use the same bilateral trade data as Frankel, stein, and Wei (1995); the data are originally from the United Nations Trade Matrix. They are for 1985, and cover trade among 63 countries. Following Frankel, stein, and Wei, observations where recorded bilateral trade is zero are dropped

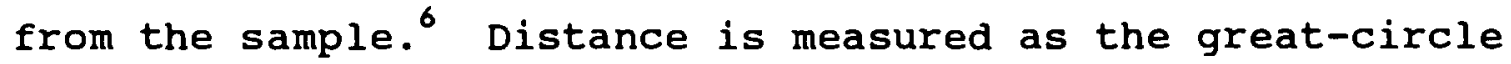
distance between countries' principal cities. The information on areas, common borders, and landlocked countries is from Rand McNally (1993). Finally, the data on population are from the Penn World Table. ${ }^{7}$

The results are shown in the first part of Table 1 . The first column shows the estimated coefficients and standard errors on the variables other than the common-border dummy and its interactions. These estimates are shown in the second column. ${ }^{8}$ The results are generally as expected. Distance has a large

6 As Frankel, stein, and Wei describe, other ways of treating these observations have little effect on the estimates.

7 We use version 5.6 of the table, which is distributed by the National Bureau of Economic Research. This is an updated version of the data described in summers and Heston (1991). Throughout the paper, population refers to the labor force. Using total population has little effect on the results.

The capital city is used as the principal city, except for a small number of cases where the capital is far from the center of the country (in terms of population). In these cases, a more centrally located large city is chosen. For the United states, for example, Chicago rather than Washington is used as the principal city.

8 The coefficient on the common-border variable itself is shown as the coefficient on the interaction of the common-border dummy with the constant. 
and overwhelmingly significant negative impact on bilateral trade; the estimated elasticity of trade with respect to distance is slightly less (in absolute value) than -1 . Trade between country $i$ and country $j$ is strongly increasing in $j$ 's size; the elasticity with respect to $j^{\prime}$ 's population is about 0.6 . In addition, trade (as a fraction of i's GDP) is decreasing in i's size and in j's area. And if one of the countries is landlocked, trade falls by about a third.

Because only a small fraction of country pairs share a border, the coefficients on the common-border variables are not precisely estimated. Nonetheless, the point estimates imply that sharing a border has a considerable effect on trade. Evaluated at the mean value of the variables conditional on sharing a border, the estimates imply that a common border raises trade by a factor of 2.2. The estimates also imply that the presence of a common border substantially alters the effects of the other variables. For example, the estimated elasticity with respect to country j's population across a shared border is 0.47 rather than 0.61 , and the estimated elasticity with respect to distance is 0.70 rather than -0.85 .

Most importantly, the regression confirms that geographic variables are major determinants of bilateral trade. The $R^{2}$ of the regression is 0.36 . Thus the results suggest that geography may be important for overall trade.

Implications for Aggregate Trade. To find the implications of our estimates for the geographic component of countries' total trade, we aggregate the fitted values from the bilateral trade 
equation. That is, we first rewrite equation (3) as

$$
\ln \left(T_{i j} / G D P_{i}\right)=a^{\prime} x_{i j}+e_{i j}
$$

where $a$ is the vector of coefficients in (3) $\left(a_{0}, a_{1}, \ldots, a_{13}\right)$, and $x_{i j}$ is the vector of right-hand side variables $\left(1\right.$, In $D_{i j}$, $\left.\ldots, B_{i j}\left[L_{i}+L_{j}\right]\right)$. our estimate of the geographic component of country i's overall trade share is then

$$
\hat{\tau}_{i}=\sum_{j \neq i} e^{\hat{a}^{\prime} x_{i j}} .
$$

Thus, our estimate of the geographic component of country i's trade is the sum of the estimated geographic components of its bilateral trade with each other country in the world.'

All that is needed to perform the calculations in equation (5) are countries' populations and geographic characteristics. We therefore take the sum in (5) not just over the countries covered by the bilateral trade data set, but over all countries in the world. ${ }^{10}$ similarly, we are able to find the constructed

9 The expectation of $T_{i j} / G D P_{i}$ conditional on $x_{i j}$ is actually equal to $e^{\hat{a} X_{i j}}$ times $E\left[e^{e_{i j}}\right]$. Since we are modeling $e_{i j}$ as homoscedastic, however, $E\left[e^{e_{i j}}\right]$ is the same for all observations, and thus multiplies $\hat{\tau}_{i}$ by a constant. This has no implications for the subsequent analysis, and is therefore omitted for simplicity.

10 For convenience, we omit a handful of countries with populations less than 100,000: Antigua and Barbuda, Greenland, Kiribati, Liechtenstein, the Marshall Islands, Micronesia, Monaco, Nauru, st. Kitts and Nevis, and San Marino. In addition, for countries that are not in the Penn World Table, we have data 
trade share, $\hat{\tau}$, for all countries, not just those for which we have bilateral trade data. Since our income regressions will also require data on openness and income, however, we limit our calculation of $\hat{\tau}$ to the countries in the Penn world Table. Thus we compute $\hat{\tau}$ for 150 countries.

The ouality of the Instrument. Figure 1 is a scatterplot of the true overall trade share, $\tau$, against the constructed share, $\hat{\tau}$. The figure shows that geographic variables account for a major part of the variation in trade. The correlation between $\tau$ and $\hat{\tau}$ is 0.62 . As column 1 of Table 2 shows, a regression of $\tau$ on a constant and $\hat{\tau}$ yields a coefficient on $\hat{\tau}$ of essentially 1 and a t-statistic of 9.5. The constructed trade share is largest for Luxembourg, Malta, Belize, the seychelles, and Grenada; all five are in the top fifth of the sample in terms of actual openness. Similarly, the constructed share is smallest for China, the United States, Brazil, India, and the Soviet Union; all five are in the bottom tenth of the sample in actual openness.

This strong correlation neglects an important issue, however. To a large extent, the relationship between actual and constructed openness just reflects the fact that smaller countries trade more. For example, the five countries with the highest constructed shares all have areas under 10,000 square

on population but not on the labor force. To estimate the labor force for these countries, we multiply their populations by the average ratio of the labor force to population among the countries in the same continent that are in the Penn world Table. We use the Penn World Table's definitions of the continents. 
miles, and the five with the lowest constructed shares all have areas over $1,000,000$ square miles. But this type of variation in openness may not be appropriate for testing the effects of trade. To see the difficulty concretely, suppose that economic activity were distributed evenly over the world's surface, and that any individual person's tendency to trade with others a given distance away was the same everywhere. Now suppose that we divided the world into countries of varying sizes, and that this division had no effect on trade between individuals. Then smaller countries would engage in more international trade, because more of the trading partners of the countries' residents would be located in different countries. But in fact the degree of trade between individuals would be the same everywhere. Thus this variation in trade between countries could not be used to infer the impact of trade on incomes. More generally, smaller countries may engage in more trade with other countries simply because they engage in less within-country trade.

Thus, in asking how openness affects incomes, we want to estimate the effect of a country's international trade on its income controlling for its size. It follows that in examining whether geographic variables provide useful information about trade, we need to ask whether they provide information beyond that contained in country size. To examine this issue, we regress countries' actual openness on a constant, our constructed measure of their openness, and our two measures of their size, $\log$ population and $\log$ area. The results are shown in the second column of Table 2. As expected, size has a negative effect on 
openness. Area is highly significant, while population is moderately so. The coefficient on constructed openness falls by slightly more than half when the size controls are added. Nonetheless, the constructed openness measure still contains a considerable amount of information about actual openness; for example, its t-statistic in the regression is 3.6 .

Figure $2 \mathrm{~A}$ shows the partial association between actual and constructed openness controlling for the size measures. The figure shows that although the relationship is not as strong as the simple relationship shown in Figure 1 , it is still positive. The figure also shows that there are two large outliers in the relationship: Luxembourg, which has extremely high fitted openness given its size, and singapore, which has extremely high actual openness given its size. Figure $2 \mathrm{~B}$ therefore shows the scatterplot with these two observations omitted. Again there is a definite positive relationship. ${ }^{11}$

The five countries with the highest constructed trade shares controlling for size are Luxembourg, Belize, Jordan, Malta, and Djibouti. All five are in densely populated parts of the world and are adjacent to large countries. Luxembourg, for example, is adjacent to Germany, France, and Belgium and is close to several other major countries. Similarly, Belize is adjacent to Mexico and Guatemala and is near the other countries of Central America and the United States. Of the five countries, Luxembourg and

11 When these two observations are dropped from the regression in Column 2 of Table 2 , the coefficient on constructed openness rises to 0.69 , but the $t$-statistic falls to 3.2 . When only Luxembourg is excluded, the coefficient is 0.64 , with a t-statistic of 2.5 . 
Jordan have large positive actual trade shares controlling for size, and the other three have moderate positive shares.

The pattern at the other extreme is similar. The five countries with the smallest constructed trade shares controlling for size, Western Samoa, Tonga, Fiji, Mauritius, and Vanuatu, are all geographically isolated islands. Of these five, Western Samoa and Tonga have large negative shares given their size, Fiji and Mauritius have moderate negative shares, and vanuatu has a moderate positive share.

\section{B. THE FACTOR ACCUMULATION APPROACH}

overview. Income is an important determinant of bilateral trade. All else equal, the higher are countries' incomes per person, the higher is their bilateral trade (see, for example, Frankel, Stein, and Wei). But simply adding measures of income to our trade equation and then proceeding along the same lines as before would not yield a valid instrument for trade. The trade share constructed using this approach would be higher for countries whose neighbors have higher incomes. But it is likely that countries with wealthy neighbors are wealthy themselves for reasons that are not related to trade. This would occur, for example, if resource endowments, institutions, or government policies are important for countries' incomes and if those factors are similar in countries that are close to one another. Thus, the overall trade share constructed using this approach would be correlated with the error term in the cross-country 
income equation, (1), and therefore would not be a valid instrument. ${ }^{12}$

There is, however, an important determinant of income that, it appears, can be used to construct an instrument. countries' rates of factor accumulation are important determinants of their incomes. Mankiw, Romer, and Weil (1992), for example, estimate a cross-country regression of the form

$$
\ln Y_{i}=c_{0}+c_{1} \ln s_{k i}+c_{2} \ln s_{h i}+c_{3} \ln \left(n_{i}+g+\delta\right)+u_{i} \text {, }
$$

where $s_{k}$ is the average ratio of real investment to real GDP, $s_{h}$ is the average fraction of the working-age population enrolled in secondary school, $\mathrm{n}$ is the average rate of population growth, and $g$ and $\delta$ are the rates of technological progress and depreciation; $g$ and $\delta$ are the same across countries, and $g+\delta$ is set to 0.05 . They find that these measures of physical capital investment, human capital investment, and population growth have large effects on income.

More importantly for our purposes, Mankiw, Romer, and Weil find that the magnitudes of the relationships between $s_{k}$, $s_{h}$, and $\mathrm{n}$ and income are close to what one would expect if these variables were uncorrelated with other determinants of income and if physical and human capital's contributions to total output were reflected by their private marginal products. Thus,

12 Elliott (1993) and Hummels (1994) show that the residuals in standard cross-country income regressions are spatially correlated. They do not provide evidence concerning whether this correlation is due to trade or to other factors. 
countries' saving and population growth rates do not appear to be strongly correlated with other determinants of income. It therefore seems unlikely, once we control for countries' own saving and population growth rates, that the saving and population growth rates of their neighbors are highly correlated with those additional determinants. But this means that these variables can be used to construct an instrument for the trade share. ${ }^{13}$

Implementation. To carry out this idea, we add income per person in the two countries to the bilateral trade equation, (3); we also add their interactions with the common-border dummy. We then estimate the equation by instrumental variables, treating these variables as endogenous and using the fitted values from equation (6) of income per person in the two countries, and their interactions with the common-border dummy, as instruments. since the data on $s_{k}, s_{h}$, and $n$ are not available for some of the countries in the bilateral trade data set, the sample size is somewhat smaller than before. ${ }^{14}$

13 Chua (1993) finds that the saving rates of a country's neighbors have a positive association with its income. He does not interpret this as reflecting an effect of trade; instead, he argues that it reflects positive externalities from capital accumulation. But if capital has positive externalities across countries, it almost surely has positive externalities within countries. Thus his interpretation is difficult to reconcile with Mankiw, Romer, and Weil's finding that the contributions of physical and human capital to output within a country suggest an absence of important externalities from capital.

14 We reestimate Mankiw, Romer, and Weil's equation using the data from version 5.6 of the Penn World Table in place of that from summers and Heston (1988). The estimated equation is

$\ln Y_{i}=\underset{(1.20)}{7.13}+\underset{(0.09)}{0.42} \ln s_{k i}+\underset{(0.07)}{0.80} \ln s_{h i}-\underset{(0.41)}{1.16} \ln \left(n_{i}+g+\delta\right)$ 
The coefficient estimates are reported in the second part of Table 1. The estimated elasticity of $T_{i j} / G D P_{i}$ with respect to income in country $j$ is 1.5 and is overwhelmingly significant; the estimated elasticity with respect to income in country i is 0.5 and is highly significant. The addition of the income variables does not change the coefficients on the other variables greatly. Implications. As before, we use the estimated bilateral trade equation to construct fitted overall trade shares. We restrict our attention to the 98 countries for which data on $s_{k}$, $s_{h}$, and $n$, and thus the fitted values of equation (6), are available. 15

$\left(\mathrm{R}^{2}=0.82\right.$, s.e.e. $\left.=0.47, \mathrm{~N}=98\right)$. These results are similar to Mankiw, Romer, and Weil's. The only notable difference is that the coefficient on $s_{k}$ is somewhat lower here, and the coefficient on $s_{h}$ is somewhat higher.

An alternative approach is to use the measures of saving and population growth (and their interactions with the common-border dummy) directly as instruments. Using this approach has virtually no effect on the results.

We also investigate two other ways of using some information about countries' incomes in constructing the instrument. The first is to enter country j's actual income into the bilateral trade equation, but to constrain it to enter with a coefficient of 1. When we do this, we omit country i's income, since we are already implicitly entering it with a coefficient of 1 through our use of $\ln \left(\mathrm{T}_{\mathrm{ij}} / \mathrm{GDP}_{\mathrm{i}}\right)$ as the dependent variable. Using this approach has little effect on the results. our second alternative is to include the two countries' actual incomes per person as of the beginning of the sample (1960) in the bilateral trade equation, and to then estimate the trade equation by OLS rather than by IV. When we do this, the resulting IV estimates of the impact of trade on income are qualitatively similar to the ones we obtain using the other approaches, but very imprecise.

15 To construct the fitted trade shares for these countries, we need estimates of their trade with all other countries, including ones for which some or all of $s_{k}, s_{h}$, and $n$ are not available. Whenever one of these variables is missing for a country, we use the mean of the variable among countries in the same continent for which it is available. other ways of addressing this issue have little effect on the results. 
Figure 3 is a scatterplot of the actual trade share against this constructed trade share for these 98 countries; the corresponding regression is reported in Column 3 of Table 2: The correlation of the actual and constructed trade shares is now 0.58 .

Again, however, what is relevant is how much information about actual trade is contained in the constructed share when size is controlled for. This issue is addressed in column 4 of Table 2 and in Figure 4. The regression shows that when the size measures are included, the constructed share enters the equation for the actual share with a t-statistic of 4.6 ; in contrast, for this sample of countries the same regression using the pure geography version of the constructed share yields a t-statistic of only 2.9. Figure 4A shows that singapore and Belgium are now significant outliers. When these two observations are dropped, neither the coefficient on the constructed share nor its standard error changes greatly. The resulting partial association is shown in Figure 4B. Thus, including information about countries' factor accumulation produces a more powerful instrument for trade.

III. ESTIMATES OF TRADE'S EFFECT ON INCOME

A. THE PURE GEOGRAPHY APPROACH

Specifications. The purpose of this section is to use the 
instruments constructed in section II to investigate the relationship between international trade and real income. The dependent variable in our regressions is log income per person. The data are for 1985, and are from the Penn World Table. All specifications include a constant and the trade share. In addition, as described in section II.A, the component of international trade that is correlated with country size is likely to reflect not variations in the overall exchange of goods, but changes in the composition of that exchange between trade with other countries and trade within a country. All specifications therefore also include the measures of country size.

In our baseline specification, we do not include any additional control variables. There are of course many other factors that may affect income. But if our argument about the appropriateness of using geographic characteristics to construct an instrument for trade is correct, there is no reason for additional independent determinants of income to be correlated with our instrument; thus they can be included in the error term. In addition, if we included other variables, the estimates of trade's impact on income would leave out any effects operating through its impact on these variables. Suppose, for example, that greater openness increases the rate of return on domestic investment and therefore raises the saving rate. Then by including the saving rate in the regression, we would be omitting openness's impact on income that operates via saving. We also consider specifications that control for other 
variables, however. Although introducing controls has the disadvantage just described, it has the advantage that it may allow us to estimate the remaining effect of openness more precisely. In addition, following the lines of Fischer's (1993) investigation of inflation and growth, we can examine the relationship between openness and the controls; thus we can gain some insight into the issue of whether openness affects income through these variables.

We consider two types of controls. The first are the measures of saving and population growth employed by Mankiw, Romer, and Weil; these are described above. The second control is countries' incomes per person as of the beginning of the sample (1960); when this variable is included, the regression becomes a "conditional convergence" regression along the lines of those estimated by Mankiw, Romer, and Weil, Barro and Sala-iMartin (1992), and others.

The data appendix reports the basic data used in the tests. It lists, for each country in the sample, its actual trade share in 1985, its constructed trade shares using both the pure geography and factor accumulation approaches, its area and population, and its income per person in $1985 .^{16}$

Samples. We focus on two samples. The first is the full set of 150 countries covered by the Penn World Table. Our instruments -- particularly the pure geography one -- are only

${ }^{16}$ The measures of saving and population growth for each country, their initial incomes, and the data used to estimate the bilateral trade equations are available from the authors on request. 
moderately correlated with openness once we control for size, and much of the variation is among the smallest countries in the sample. Thus it is important to consider a relatively broad sample. And as we describe below, the results for this sample are robust to the exclusion of outliers and of observations where the data are potentially the most subject to error.

our second sample is the 98-country sample considered by Mankiw, Romer, and Weil. Focusing on this sample is necessary when we want to control for saving and population growth. In addition, the countries in this sample generally have more reliable data; they are also generally larger, and thus less likely to have their incomes determined by idiosyncratic factors. Basic Results. Tables $3 \mathrm{~A}$ and $3 \mathrm{~B}$ report the regressions. Table $3 \mathrm{~A}$ shows the specifications without any additional control variables; Table 3B shows the specifications where additional controls are included. Column 1 of Table $3 \mathrm{~A}$ is an oLs regression of log income per person on a constant and the two size measures. The regression shows a statistically and economically significant relationship between the trade share and income. The t-statistic on the trade share is 3.5 ; the point estimates imply that an increase of one percentage point in the shares of both exports and imports in GDP is associated with an increase of $1.7 \%$ in income per person. The regression also suggests that, controlling for international trade, there is a positive (though only marginally significant) relation between country size and income per person; this result is what one would expect if trade is beneficial and if the component of international trade that is 
correlated with size reflects shifts between trade within a country and trade with other countries. The point estimates imply that increasing both population and area by one percent raises income per person by $0.1 \% .^{17}$

column 2 reports the IV estimates of the same equation. The trade share is treated as endogenous, and the pure geography version of the constructed trade share is used as an instrument. The coefficient on openness rises sharply. That is, the point estimate suggests that examining the link between trade and income using oLs understates rather than overstates the effect of trade. The estimates now imply that one-percentage-point increases in the export and import shares raise income per person by $3.9 \%$. In addition, the hypothesis that the IV coefficient is zero is rejected at conventional levels $(t=2.2)$. The coefficient is much less precisely estimated under IV than under OLS, however. As a result, the hypothesis that the IV and OLS estimates are equal cannot be rejected $(t=1.1) .^{18}$

17 Without information on the extent of within-country trade and how it varies with country size, there does not appear to be any natural way to compare the magnitudes of the coefficients on size and the coefficient on openness.

18 As the table reports, the F-statistic in the first-stage regression on the variable that is included in the instrument list but excluded from the second-stage regression -- namely the constructed trade share -- is 13.1. In the IV regressions discussed below, this statistic is generally between 6 and 10 . Thus, consistent with the discussion in the previous section, the constructed trade share has a moderate amount of explanatory power for actual trade given the control variables. The results of Nelson and Startz (1990), Hall, Rudebusch, and Wilcox (1994), and others suggest that these first-stage F-statistics are large enough that the finite-sample bias of instrumental variables -which biases the IV estimate toward the OLS estimate -- is unlikely to be a serious problem in the regressions. 
Columns 3 and 4 consider the 98-country sample. This change has little effect on the oLs estimate of the coefficient on openness, but raises both the IV estimate and its standard error considerably. The t-statistic for the oLs estimate falls moderately, while the one for the IV estimate changes little.

Table 3B shows the effects of including the control

variables. All of the regressions that include controls use the 98-country sample. Columns 1 and 2 add the measures of saving and population growth. These variables enter with the expected signs, and with magnitudes broadly similar to those found by Mankiw, Romer, and Weil. Their inclusion drives the oLs estimate of the effect of openness to virtually zero. The IV estimate falls sharply as well, and is no longer significantly different from zero; the point estimate remains large, however.

Columns 3 and 4 show the effects of including log income per person in 1960. Not surprisingly, this variable is quantitatively important and overwhelmingly significant in predicting income in 1985. Its inclusion, like the inclusion of the factor accumulation variables, lowers both the oLs and IV estimates of the effect of openness. The standard errors also fall, however. As a result, the ols estimate is overwhelmingly significant $(t=4.0)$, and the IV estimate is clearly so $(t=2.5)$. And once again, the IV estimate is much larger than the oLs estimate.

Finally, Columns 5 and 6 show the effects of including all of the control variables. The estimated effect of trade is small under OLS and moderate under IV; the t-statistics on both 
estimates are roughly two.

Robustness. A natural question is whether these results are robust. We consider robustness along four dimensions.

First, as described above, Luxembourg and singapore are major outliers in the relationship between the actual and constructed trade shares. Dropping either or both of these observations, however, does not change the basic pattern of the results. The most noticeable change occurs when Luxembourg is dropped from the baseline regressions in columns 1 and 2 of Table 3A. This has effects similar to those of moving to the 98country sample (which does not include Luxembourg): the oLs estimate is little changed, but the IV estimate and its standard error rise. Similarly, adding Luxembourg to the regressions in Columns 3 and 4 of Table 3A moderately reduces the IV estimate of the effect of openness. The treatment of these two observations has no important impact on any of the other regressions.

A second concern is the possibility that systematic differences among parts of the world are driving the results. That is, it could be that our IV estimates of the impact of trade arise because the countries in certain regions of the world have systematically higher constructed trade shares given their size and also have systematically higher incomes. In this case, our findings might be the result not of trade, but of other features of those regions.

To address this concern, we reestimate the regressions in Table 3 including a dummy variable for each continent. This modification substantially increases the standard errors of the 
IV estimates of the impact of trade on income; as a result, the estimates are no longer significantly different from zero. The point estimates of the effects of trade change little, however. The only noteworthy effect is that the IV estimate of the impact of trade in the baseline regression in column 2 of Table $3 \mathrm{~A}$ falls to only slightly above the oLs estimate. When Luxembourg is dropped from the sample, however, the IV estimate returns to being much larger than the oLs estimate.

Third, our data are highly imperfect in various ways.

Potentially most important, for the major oil-producing countries much of measured GDP represents the sale of existing resources rather than genuine value added. Since these countries have among the highest measured incomes in the sample, they have the potential to affect the results substantially. In fact, however, they are not important to our findings: they are already absent from the 98-country sample, and excluding them from the 150country sample changes the estimates only slightly. As a more general check of the possible importance of data problems, we use the Penn World Table's summary assessments of the quality of countries' data to exclude the countries with the poorest data from the sample. Specifically, we exclude all countries whose data are assigned a grade of "D"; this reduces the 150-country sample to 99, and the 98-country sample to 77 . These reductions in the sample sizes moderately increase the standard errors of both the OLS and IV estimates of the impact of trade; the point estimates change little, however.

Finally, one can imagine reasons that virtually all of the 
variables used in finding the geographic component of countries' trade might have some endogenous component that is correlated with the error term in the income equation. For example, whether countries have access to the ocean may be endogenous in the truly long run, and may be determined in part by other forces that affect their incomes. Similarly, population is endogenous in the very long run. To check that no single variable that could conceivably be endogenous is driving the results, we redo the construction of the instruments and the regressions in Table 3 in four ways: omitting the landlocked variable from the bilateral trade equation; excluding population from the bilateral trade equation; omitting all interactions with the common-border dummy from this equation; and using total population rather than the labor force both in measuring countries' sizes and in computing income per person.

None of these changes has a major effect on the results. Using population in place of the labor force lowers the IV estimate of the effect of trade in column 2 of Table $3 B$ to only slightly above the oLs estimate, and omitting population from the bilateral trade equation altogether has a similar effect on the IV estimate in column 4 of the table. But there are also several cases where these changes considerably raise the IV estimate, or considerably reduce its standard error. More importantly, none of the changes alters the overall pattern of the results. Thus, our findings do not hinge on the use of any of these variables in constructing the fitted trade shares.

In addition, we investigate the robustness of the results in 
Tables 4 and 5 below along these same dimensions. The basic finding is the same: although the results sometimes change moderately, their overall pattern is unaffected.

Trade and other Determinants of Income. The results in Table 3B suggest that an important part of trade's effect on income may operate through its impact on rates of factor accumulation and on income in 1960. To investigate this possibility, Table 4 reports regressions of each of the control variables considered in Table $3 B$ on a constant, openness, and the size measures. Again we consider both oLs and IV estimates. The results are remarkably consistent across the different variables. The point estimates using instrumental variables suggest that trade raises income by increasing physical capital and human capital accumulation, reducing population growth, and raising initial income. And in each case, the point estimates suggest that the impact of trade is substantial. The estimates imply that a one-percentage-point increase in the export and import shares raises initial income and both of the saving rates by about three percent, and lowers $n+g+\delta$ by about half a percent. Further, in every case, the estimates suggest that country size, controlling for international trade, is beneficial. This is consistent with the view that trade, either within a country or between countries, increases income. And in every case the IV estimate of the income-enhancing effects of trade is substantially larger than the oLs estimate.

The standard errors of the IV estimates of the estimates of openness are large, however. Only for physical capital 
investment is the estimate significantly different from zero $(t=2.1)$. For schooling, population growth, and initial income, the t-statistics range from 1.5 to 1.7 . Thus, although the estimates suggest that openness raises incomes through several different channels, they do not allow us to determine its contribution through each channel with great precision. ${ }^{19}$

\section{B. THE FACTOR ACCUMULATION APPROACH}

We now turn to the case where the instrument for the trade share also employs information on partners' saving and population growth. Because the factor accumulation variables are now used in constructing the instrument, we consider only the specifications that also include these variables as controls for income. And because these variables are available only for the 98-country sample, we focus on this sample.

Table 5 reports the results; the oLs estimates in columns 1 and 3 repeat the regressions in columns 1 and 5 of Table 3B. As expected, the use of information on partners' factor accumulation allows us to estimate the impact of openness more precisely. In the specification that excludes the country's initial income (Column 2), the standard error is about one-third smaller than

19 Adding the continent dummies largely eliminates the difference between the OLS and IV estimates of the effects of trade on population growth, and lowers the t-statistic on the IV estimate of the effect of openness on physical capital investment to 1.5. Otherwise, the results in Table 4 are not greatly affected by the exclusion of outliers, the addition of continent dummies, the omission of countries with the most questionable data, and the use of less information in constructing the instrument. 
when the pure geography version of the instrument is used; and in the specification that includes initial income (Column 4 ), it is more than one-half smaller. In addition, the change to the factor accumulation version of the instrument does not systematically change the estimated effects of openness: the estimate rises slightly when initial income is excluded, and falls moderately when it is included. The t-statistic for the null hypothesis that the estimates are equal using the two instruments is 0.4 for the first specification and -1.3 for the second. $^{20}$ The fact that the estimates do not change consistently when we use the instrument based on factor accumulation supports our argument that this is a valid instrument.

Even with the use of partners' saving and population growth to construct the instrument, the effects of trade are not estimated very precisely. For the specification that excludes the country's initial income, the IV estimate is significantly larger than the oLs estimate $(t=2.2)$, and significantly larger than zero $(t=2.1)$. The two-standard-error confidence interval is wide, however: the estimates imply that a one-percentagepoint increase in the export and import shares, holding domestic factor accumulation fixed, raises income by between $0.1 \%$ and 3.98. For the specification that includes the country's initial

20 The factor accumulation instrument is based on strictly more information than the pure geography version. Thus under the null hypothesis that both instruments are valid, the estimate using the pure geography instrument equals the estimate using the factor accumulation version plus an uncorrelated error. The variance of the difference between the two estimates is therefore just the difference in their variances. 
income, the IV estimate is not significantly different from the OLS estimate $(t=1.3)$, and is marginally significantly different from zero $(t=2.0)$. The two-standard-error confidence interval implies that a one-percentage-point increase in the trade shares, holding domestic factor accumulation and initial income constant, changes income by between $0.0 \%$ and $1.8 \% .^{21}$

\section{CONCLUSION}

This paper investigates the question of how international trade affects standards of living. Although this is an old question, it is a difficult one to answer. Countries' degrees of openness are not determined exogenously. As a result, correlations between openness and income cannot identify the effect of trade.

This paper addresses this problem by focusing on the component of openness that is due to geographic factors. Some countries trade more just because they are near well-populated countries, and some trade less because they are isolated. This component of the variation in openness is not a consequence of differences in income or in government policy. Thus there is no reason for it to be systematically correlated with other determinants of income: there is no likely channel through which

21 Adding the continent dummies reduces the IV estimate of the impact of openness on income in Column 4 of Table 5 to essentially the same value as the oLs estimate. Otherwise, the results in the Table 5 are largely robust to the issues discussed above. 
proximity or isolation affects income other than increased or decreased interactions with other countries. Thus, the variation in openness that is due to geographic factors can serve as a natural experiment for identifying the effects of trade.

The results of the experiment are consistent across the samples and specifications we consider: trade raises income. The relation between the geographic component of openness and income suggests that a rise of one percentage point in the shares of imports and exports in GDP increases income per person by two percent or more. Openness appears to raise income both by spurring factor accumulation and by increasing output for a given level of accumulation.

The results also suggest that simply examining the relationship between income and overall openness yields an underestimate of the effects of trade. This could arise if protectionist policies are a luxury good, so that countries that are wealthy for reasons other than trade are more prone to protection.

There are two important caveats to these conclusions. First, the effects of trade are not estimated with great precision. The hypothesis that the impact of trade is zero is typically rejected at standard significance levels, but the rejections are not overwhelming. In addition, the hypothesis that the estimate based on the geographic component of openness is the same as the estimate based on overall openness is typically relatively far from rejection. Thus, although the results bolster the case for the benefits of trade, they do not 
provide decisive evidence for it.

This limitation is probably inherent in the experiment we are considering. Once country size is controlled for, geography appears to account for only a moderate part of the variation in openness. As a result, the geographic variables provide only a limited amount of information about the relation between trade and income. Thus, unless additional portions of overall trade that are unaffected by other determinants of income can be identified, it is likely to be difficult to improve greatly on our estimates of the effects of trade.

The second limitation of the results is that they cannot be applied without qualification to the effects of trade policies. There are many ways that trade affects income, and it is unlikely that variations in openness that are due to geography and variations that are due to policy involve exactly the same mix of the various mechanisms. Thus, differences in openness resulting from policy may not affect income in precisely the same way as differences resulting from geography.

There are at least four general channels through which trade affects income. First, of course, trade allows countries to specialize according to comparative advantage. Second, as modern trade theory emphasizes, trade allows greater exploitation of increasing returns. Third, trade can affect economic performance through its impact on the political process. Krueger (1974), for example, argues that trade restrictions encourage lobbying and other rent-seeking actions at the expense of productive activities. Finally, trade can affect the technologies that 
countries have available through such channels as direct investment by foreign firms with proprietary knowledge, increased contact with foreigners, and reduced incentives for domestic research and development (see Rivera-Batiz and Romer, 1991, and Pack and Page, 1994, for further discussion).

In the cases of comparative advantage, increasing returns, and technology, there is no evident reason for the effects of variations in openness coming from policy to differ substantially from the effects of variations in openness coming from geography. In the case of the political channel, in contrast, the effects of variations in openness coming from the two sources may be quite different. The variations in openness resulting from geography cannot be the subject of political pressures for change, whereas the variations resulting from policy can be. Thus variations in openness that stem from policy are likely to have more of an impact on income through political channels than are similar variations in openness that stem from geography. It follows that if protectionist policies' impact on income through political channels is negative, their overall effect on income is likely to be even more negative than the effect of similar variations in trade resulting from geography. If this is right, then our results suggest not just that increased trade is highly beneficial to standards of living, but that increased trade coming from trade policy is especially beneficial. 


\section{REFERENCES}

Barro, Robert J., and Xavier Sala-i-Martin. 1992.

"Convergence." Journal of Political Economy 100 (April): 223-251.

Bradford, Colin, Jr., and Naomi Chakwin. 1993. "Alternative Explanations of the Trade-output Correlation in East Asian Economies." OECD Development Centre Technical Papers, No. 87 (August).

Chua, Hak B. 1993. "Regional Spillovers and Economic Growth." Unpublished paper, Yale University (June).

Deardorff, Alan w. 1984. "Testing Trade Theories and Predicting Trade Flows." In Ronald Jones and Peter Kenen, eds., Handbook of International Economics, vol. 1, 467-517. Amsterdam: North-Holland.

De Long. J. Bradford, and Lawrence H. Summers. 1991. "Equipment Investment and Economic Growth." Quarterly Journal of Economics 106 (May): 445-502.

Dollar, David. 1992. "Outward-Oriented Developing Economies Really Do Grow More Rapidly: Evidence from 95 LDCs, 19761985." Economic Development and Cultural Change 40: 523544 .

Easterly, william. 1993. "How Much Do Distortions Affect Growth?" Journal of Monetary Economics 32 (November) : 187212 .

Edwards, Sebastian. 1993a. "Openness, Trade Liberalization, and Growth in Developing Countries." Journal of Economic Literature 31 (September): 1358-1393.

Edwards, Sebastian. 1993b. "Trade Policy, Exchange Rates and Growth." National Bureau of Economic Research Working Paper No. 4511 (October).

Elliott, Graham. 1993. "Spatial Correlation and cross Country Regressions." Unpublished paper, Harvard University (July).

Feder, Gershon. 1983. "On Exports and Economic Growth." Journal of Development Economics 12 (April): 59-73.

Fischer, Stanley. 1991. "Growth, Macroeconomics, and Development." NBER Macroeconomics Annual 6: 329-364. 
Fischer, stanley. 1993. "The Role of Macroeconomic Factors in Growth." Journal of Monetary Economics 32 (December): 485512 .

Frankel, Jeffrey, 1996. Regional Trading Blocs. Washington, D.C.: Institute of International Economics, forthcoming.

Frankel, Jeffrey, Ernesto Stein, and Shang-Jin Wei. 1993. "Trading Blocs and the Americas: The Natural, the Unnatural, and the Super-Natural." Journal of Development Economics 47: 61-95.

Harrison, Ann. 1995. "Openness and Growth: A Time-Series, Cross-Country Analysis for Developing Countries." National Bureau of Economic Research Working Paper No. 5221 (August).

Hall, Alastair R., Glenn D. Rudebusch, and David W. Wilcox. 1994. "Judging Instrument Relevance in Instrumental Variables Estimation." Unpublished paper, Federal Reserve Board (September).

Helpman, Elhanan. 1988. "Growth, Technological Progress, and Trade." National Bureau of Economic Research Reprint No. 1145 .

Hummels, David. 1994. "Global Income clustering and Trade in Intermediate Goods." Unpublished paper, University of Michigan (October).

Kormendi, Roger C., and Philip G. Meguire. 1985. "Macroeconomic Determinants of Growth: Cross-Country Evidence." Journal of Monetary Economics 16 (September): 141-163.

Krueger, Anne 0. 1974. "The Political Economy of the RentSeeking Society." American Economic Review 64 (June): 291303 .

Lee, Jong-Wha. 1993. "International Trade, Distortions and Long-Run Economic Growth." IMF Staff Papers 40 (June): 299328 .

Levine, Ross, and David Renelt. 1992. "A Sensitivity Analysis of Cross-Country Growth Regressions." American Economic Review 82 (September): 942-963.

Linneman, Hans. 1966. An Econometric study of International Trade Flows. Amsterdam: North-Holland.

Mankiw, N. Gregory, David Romer, and David N. Weil. 1992. "A Contribution to the Empirics of Economic Growth." Quarterly Journal of Economics 107 (May): 407-437. 
Michaely, Michael. 1977. "Exports and Growth: An Empirical Investigation." Journal of Development Economics 4 (March): 49-53.

Nelson, Charles R., and Richard Startz. 1990. "Some Further Results on the Exact Small Sample Properties of the Instrumental Variable Estimator." Econometrica 58 (July): 967-976.

Pack, Howard, and John M. Page, Jr. 1994. "Accumulation, Exports, and Growth in the High-Performing Asian Economics." Carnegie-Rochester conference series on Public Policy (June): 199-235.

Quah, Danny, and James Rauch. 1990. "Openness and the Rate of Economic Growth." Unpublished paper, University of California, San Diego (October).

Rand McNally. 1993. Quick Reference World Atlas.

Rivera-Batiz, Luis A., and Paul M. Romer. 1991. "Economic Integration and Endogenous Growth." Quarterly Journal of Economics 106 (May): 531-555.

Rodrik, Dani. 1993. "Trade and Industrial Policy Reform in Developing Countries: A Review of Recent Theory and Evidence." National Bureau of Economic Research Working Paper No. 4417 (August).

Rodrik, Dani. 1994. "Getting Interventions Right: How South Korea and Taiwan Grew Rich." National Bureau of Economic Research Working Paper No. 4964 (December). Economic Policy, forthcoming.

Sala-i-Martin, Xavier. 1991. "Comment." NBER Macroeconomics Annual 6: 368-378.

Summers, Robert, and Alan Heston. 1988. "A New set of International Comparisons of Real Product and Price Levels: Estimates for 130 Countries, 1950-85." Review of Income and Wealth 34 (March): 1-26.

Summers, Robert, and Alan Heston. 1991. "The Penn World Table (Mark 5): An Expanded Set of International Comparisons, 1950-1988." Quarterly Journal of Economics 106 (May): 327368 . 
TABLE 1

BILATERAL TRADE EQUATIONS

\begin{tabular}{|c|c|c|c|c|}
\hline \multirow{3}{*}{ Estimation } & \multicolumn{2}{|c|}{ (1) } & \multicolumn{2}{|c|}{$(2)$} \\
\hline & \multicolumn{2}{|c|}{ OLS } & \multicolumn{2}{|c|}{ IV } \\
\hline & $\underline{\text { Variable }}$ & $\begin{array}{l}\text { Inter- } \\
\text { action }\end{array}$ & Variable & $\begin{array}{l}\text { Inter- } \\
\text { action }\end{array}$ \\
\hline Constant & $\begin{array}{l}-6.38 \\
(0.42)\end{array}$ & $\begin{array}{c}5.10 \\
(1.78)\end{array}$ & $\begin{array}{r}-28.83 \\
(0.71)\end{array}$ & $\begin{array}{c}8.38 \\
(2.68)\end{array}$ \\
\hline Ln Distance & $\begin{array}{l}-0.85 \\
(0.04)\end{array}$ & $\begin{array}{c}0.15 \\
(0.30)\end{array}$ & $\begin{array}{l}-0.79 \\
(0.03)\end{array}$ & $\begin{array}{c}0.35 \\
(0.24)\end{array}$ \\
\hline $\begin{array}{l}\text { Ln Population } \\
\text { (country i) }\end{array}$ & $\begin{array}{l}-0.24 \\
(0.03)\end{array}$ & $\begin{array}{l}-0.29 \\
(0.18)\end{array}$ & $\begin{array}{l}-0.07 \\
(0.02)\end{array}$ & $\begin{array}{l}-0.41 \\
(0.14)\end{array}$ \\
\hline $\begin{array}{l}\text { Ln Area } \\
(\text { country i) }\end{array}$ & $\begin{array}{l}-0.12 \\
(0.02)\end{array}$ & $\begin{array}{l}-0.06 \\
(0.15)\end{array}$ & $\begin{array}{l}-0.19 \\
(0.01)\end{array}$ & $\begin{array}{c}0.09 \\
(0.12)\end{array}$ \\
\hline $\begin{array}{l}\text { Ln Population } \\
(\text { country } j)\end{array}$ & $\begin{array}{c}0.61 \\
(0.03)\end{array}$ & $\begin{array}{l}-0.14 \\
(0.18)\end{array}$ & $\begin{array}{c}0.93 \\
(0.02)\end{array}$ & $\begin{array}{l}-0.41 \\
(0.14)\end{array}$ \\
\hline $\begin{array}{l}\text { Ln Area } \\
(\text { country j) }\end{array}$ & $\begin{array}{l}-0.19 \\
(0.02)\end{array}$ & $\begin{array}{l}-0.07 \\
(0.15)\end{array}$ & $\begin{array}{l}-0.19 \\
(0.01)\end{array}$ & $\begin{array}{c}0.09 \\
(0.12)\end{array}$ \\
\hline Landlocked & $\begin{array}{l}-0.36 \\
(0.08)\end{array}$ & $\begin{array}{c}0.33 \\
(0.33)\end{array}$ & $\begin{array}{l}-0.12 \\
(0.07)\end{array}$ & $\begin{array}{l}-0.03 \\
(0.28)\end{array}$ \\
\hline $\begin{array}{l}\text { Ln Inc./Pop. } \\
\text { (country i) }\end{array}$ & & & $\begin{array}{c}0.47 \\
(0.03)\end{array}$ & $\begin{array}{l}-0.24 \\
(0.36)\end{array}$ \\
\hline $\begin{array}{l}\text { Ln Inc./Pop. } \\
(\text { country } j)\end{array}$ & & & $\begin{array}{c}1.47 \\
(0.03)\end{array}$ & $\begin{array}{l}-0.24 \\
(0.36)\end{array}$ \\
\hline Sample Size & & & & \\
\hline $\mathrm{R}^{2}$ & & & & \\
\hline s.e.e. & & & & \\
\hline
\end{tabular}

The dependent variable is $\ln \left(\mathrm{T}_{i j} / \mathrm{GDP}_{i}\right)$. The first column for each equation reports the coefficient on the variable listed, and the second column reports the coefficient on the variable's interaction with the common-border dummy. Standard errors are in parentheses. 
TABLE 2

THE RELATION BETWEEN ACTUAL AND FITTED OPENNESS

\begin{tabular}{|c|c|c|c|c|}
\hline & (1) & $(2)$ & (3) & $(4)$ \\
\hline Constant & $\begin{array}{l}46.41 \\
(4.10)\end{array}$ & $\begin{array}{l}166.97 \\
(18.88)\end{array}$ & $\begin{array}{l}36.59 \\
(4.97)\end{array}$ & $\begin{array}{l}176.60 \\
(28.20)\end{array}$ \\
\hline $\begin{array}{l}\text { Constructed Openness } \\
\text { (Pure Geography) }\end{array}$ & $\begin{array}{c}0.99 \\
(0.10)\end{array}$ & $\begin{array}{c}0.45 \\
(0.12)\end{array}$ & & \\
\hline $\begin{array}{l}\text { Constructed Openness } \\
\text { (Factor Accumulation) }\end{array}$ & & & $\begin{array}{c}1.54 \\
(0.22)\end{array}$ & $\begin{array}{l}1.11 \\
(0.24)\end{array}$ \\
\hline Ln Population & & $\begin{array}{l}-4.72 \\
(2.06)\end{array}$ & & $\begin{array}{l}-8.98 \\
(2.87)\end{array}$ \\
\hline Ln Area & & $\begin{array}{l}-6.45 \\
(1.77)\end{array}$ & & $\begin{array}{l}-4.98 \\
(2.49)\end{array}$ \\
\hline Sample Size & 150 & 150 & 98 & 98 \\
\hline $\mathbf{R}^{2}$ & 0.38 & 0.52 & 0.34 & 0.49 \\
\hline S.e.e. & 36.33 & 32.19 & 34.71 & 30.77 \\
\hline
\end{tabular}

The dependent variable is actual openness. Standard errors are in parentheses. 
TABLE 3A

TRADE AND INCOME - PURE GEOGRAPHY APPROACH (NO CONTROLS)

\begin{tabular}{|c|c|c|c|c|}
\hline & $(1)$ & $(2)$ & (3) & $(4)$ \\
\hline Estimation & OLS & IV & OLS & IV \\
\hline Constant & $\begin{array}{c}7.40 \\
(0.66)\end{array}$ & $\begin{array}{c}4.96 \\
(2.04)\end{array}$ & $\begin{array}{c}6.95 \\
(1.12)\end{array}$ & $\begin{array}{c}1.62 \\
(3.48)\end{array}$ \\
\hline Openness & $\begin{array}{c}0.85 \\
(0.25)\end{array}$ & $\begin{array}{c}1.97 \\
(0.91)\end{array}$ & $\begin{array}{c}0.82 \\
(0.32)\end{array}$ & $\begin{array}{c}2.96 \\
(1.34)\end{array}$ \\
\hline Ln Population & $\begin{array}{c}0.12 \\
(0.06)\end{array}$ & $\begin{array}{c}0.19 \\
(0.09)\end{array}$ & $\begin{array}{c}0.21 \\
(0.10)\end{array}$ & $\begin{array}{c}0.35 \\
(0.15)\end{array}$ \\
\hline Ln Area & $\begin{array}{l}-0.01 \\
(0.06)\end{array}$ & $\begin{array}{c}0.09 \\
(0.10)\end{array}$ & $\begin{array}{l}-0.05 \\
(0.08)\end{array}$ & $\begin{array}{c}0.20 \\
(0.18)\end{array}$ \\
\hline Sample Size & 150 & 150 & 98 & 98 \\
\hline $\mathrm{R}^{2}$ & 0.09 & 0.09 & 0.11 & 0.09 \\
\hline S.e.e. & 1.00 & 1.06 & 1.04 & 1.27 \\
\hline $\begin{array}{l}\text { First-Stage F } \\
\text { on Excluded } \\
\text { Instruments }\end{array}$ & & 13.13 & & 8.45 \\
\hline
\end{tabular}

The dependent variable is log income per person in 1985 . Standard errors are in parentheses. 
TABLE 3B

TRADE AND INCOME - - PURE GEOGRAPHY APPROACH (WITH CONTROLS)

\begin{tabular}{|c|c|c|c|c|c|c|}
\hline & $(1)$ & (2) & $(3)$ & (4) & $(5)$ & $(6)$ \\
\hline Estimation & OLS & IV & OLS & IV & OLS & IV \\
\hline Constant & $\begin{array}{c}7.27 \\
(1.30)\end{array}$ & $\begin{array}{c}5.40 \\
(2.15)\end{array}$ & $\begin{array}{l}-0.61 \\
(0.49)\end{array}$ & $\begin{array}{l}-2.53 \\
(1.26)\end{array}$ & $\begin{array}{c}2.19 \\
(0.87)\end{array}$ & $\begin{array}{l}-0.37 \\
(1.93)\end{array}$ \\
\hline Openness & $\begin{array}{c}0.00 \\
(0.16)\end{array}$ & $\begin{array}{c}0.83 \\
(0.71)\end{array}$ & $\begin{array}{c}0.44 \\
(0.11)\end{array}$ & $\begin{array}{l}1.35 \\
(0.54)\end{array}$ & $\begin{array}{c}0.17 \\
(0.09)\end{array}$ & $\begin{array}{l}1.09 \\
(0.54)\end{array}$ \\
\hline Ln Population & $\begin{array}{l}-0.04 \\
(0.05)\end{array}$ & $\begin{array}{c}0.02 \\
(0.07)\end{array}$ & $\begin{array}{c}0.12 \\
(0.03)\end{array}$ & $\begin{array}{c}0.18 \\
(0.06)\end{array}$ & $\begin{array}{c}0.05 \\
(0.03)\end{array}$ & $\begin{array}{c}0.12 \\
(0.06)\end{array}$ \\
\hline Ln Area & $\begin{array}{c}0.01 \\
(0.04)\end{array}$ & $\begin{array}{c}0.10 \\
(0.09)\end{array}$ & $\begin{array}{l}-0.03 \\
(0.03)\end{array}$ & $\begin{array}{c}0.08 \\
(0.07)\end{array}$ & $\begin{array}{l}-0.02 \\
(0.02)\end{array}$ & $\begin{array}{c}0.08 \\
(0.06)\end{array}$ \\
\hline Ln $s_{k}$ & $\begin{array}{c}0.42 \\
(0.10)\end{array}$ & $\begin{array}{c}0.24 \\
(0.18)\end{array}$ & & & $\begin{array}{c}0.26 \\
(0.06)\end{array}$ & $\begin{array}{c}0.06 \\
(0.15)\end{array}$ \\
\hline Ln $s_{h}$ & $\begin{array}{c}0.81 \\
(0.08)\end{array}$ & $\begin{array}{c}0.84 \\
(0.09)\end{array}$ & & & $\begin{array}{c}0.28 \\
(0.06)\end{array}$ & $\begin{array}{l}0.26 \\
(0.09)\end{array}$ \\
\hline $\operatorname{Ln}(n+g+\delta)$ & $\begin{array}{l}-1.20 \\
(0.42)\end{array}$ & $\begin{array}{l}-1.33 \\
(0.49)\end{array}$ & & & $\begin{array}{l}-0.31 \\
(0.26)\end{array}$ & $\begin{array}{l}-0.35 \\
(0.37)\end{array}$ \\
\hline $\begin{array}{l}\text { In Initial } \\
\text { Inc./Pop. }\end{array}$ & & & $\begin{array}{c}1.01 \\
(0.04)\end{array}$ & $\begin{array}{c}0.97 \\
(0.06)\end{array}$ & $\begin{array}{c}0.69 \\
(0.05)\end{array}$ & $\begin{array}{c}0.76 \\
(0.09)\end{array}$ \\
\hline Sample Size & 98 & 98 & 98 & 98 & 98 & 98 \\
\hline $\mathrm{R}^{2}$ & 0.82 & 0.77 & 0.89 & 0.83 & 0.94 & 0.88 \\
\hline S.e.e. & 0.48 & 0.54 & 0.36 & 0.48 & 0.28 & 0.40 \\
\hline $\begin{array}{l}\text { First-Stage F } \\
\text { on Excluded } \\
\text { Instruments }\end{array}$ & & 6.21 & & 7.39 & & 5.93 \\
\hline
\end{tabular}

The dependent variable is log income per person in 1985. Standard errors are in parentheses. 
TABLE 4

TRADE AND OTHER DETERMINANTS OF INCOME

\begin{tabular}{|c|c|c|c|c|c|c|c|c|}
\hline & $(1)$ & $(2)$ & $(3)$ & (4) & (5) & $(6)$ & $(7)$ & $(8)$ \\
\hline $\begin{array}{c}\text { Dependent } \\
\text { Variable }\end{array}$ & \multicolumn{2}{|c|}{$\ln s_{k}$} & \multicolumn{2}{|c|}{$\ln s_{h}$} & \multicolumn{2}{|c|}{$\ln (n+g+\delta)$} & \multicolumn{2}{|c|}{$\ln \left(Y_{0} /\right.$ Pop. $)$} \\
\hline Estimation & OLS & IV & OLS & IV & OLS & IV & OLS & IV \\
\hline Constant & $\begin{array}{c}0.28 \\
(0.72)\end{array}$ & $\begin{array}{l}-1.39 \\
(1.95)\end{array}$ & $\begin{array}{l}-4.49 \\
(0.92)\end{array}$ & $\begin{array}{l}-7.24 \\
(2.56)\end{array}$ & $\begin{array}{l}-2.66 \\
(0.13)\end{array}$ & $\begin{array}{l}-1.96 \\
(0.41)\end{array}$ & $\begin{array}{c}7.45 \\
(1.03)\end{array}$ & $\begin{array}{c}4.27 \\
(2.90)\end{array}$ \\
\hline Openness & $\begin{array}{c}0.87 \\
(0.20)\end{array}$ & $\begin{array}{c}1.54 \\
(0.75)\end{array}$ & $\begin{array}{c}0.58 \\
(0.26)\end{array}$ & $\begin{array}{c}1.68 \\
(0.99)\end{array}$ & $\begin{array}{c}0.01 \\
(0.04)\end{array}$ & $\begin{array}{l}-0.27 \\
(0.16)\end{array}$ & $\begin{array}{c}0.38 \\
(0.29)\end{array}$ & $\begin{array}{c}1.66 \\
(1.11)\end{array}$ \\
\hline Ln Pop. & $\begin{array}{c}0.13 \\
(0.06)\end{array}$ & $\begin{array}{c}0.18 \\
(0.08)\end{array}$ & $\begin{array}{c}0.22 \\
(0.08)\end{array}$ & $\begin{array}{c}0.30 \\
(0.11)\end{array}$ & $\begin{array}{l}-0.01 \\
(0.01)\end{array}$ & $\begin{array}{l}-0.03 \\
(0.02)\end{array}$ & $\begin{array}{c}0.09 \\
(0.09)\end{array}$ & $\begin{array}{c}0.17 \\
(0.12)\end{array}$ \\
\hline Ln Area & $\begin{array}{c}0.05 \\
(0.05)\end{array}$ & $\begin{array}{c}0.13 \\
(0.10)\end{array}$ & $\begin{array}{l}-0.09 \\
(0.06)\end{array}$ & $\begin{array}{c}0.04 \\
(0.13)\end{array}$ & $\begin{array}{c}0.01 \\
(0.01)\end{array}$ & $\begin{array}{l}-0.02 \\
(0.02)\end{array}$ & $\begin{array}{l}-0.02 \\
(0.07)\end{array}$ & $\begin{array}{c}0.13 \\
(0.15)\end{array}$ \\
\hline Sample Size & 98 & 98 & 98 & 98 & 98 & 98 & 98 & 98 \\
\hline $\mathrm{R}^{2}$ & 0.17 & 0.17 & 0.13 & 0.10 & 0.02 & 0.00 & 0.03 & 0.02 \\
\hline S.e.e. & 0.67 & 0.71 & 0.86 & 0.94 & 0.12 & 0.15 & 0.96 & 1.06 \\
\hline $\begin{array}{c}\text { First-Stage F } \\
\text { on Excluded } \\
\text { Instruments }\end{array}$ & & 8.45 & & 8.45 & & 8.45 & & 8.45 \\
\hline
\end{tabular}

Standard errors are in parentheses. 
TABLE 5

TRADE AND INCOME - - FACTOR ACCUMULATION APPROACH

\begin{tabular}{|c|c|c|c|c|}
\hline & (1) & $(2)$ & $(3)$ & $(4)$ \\
\hline Estimation & OLS & IV & OLS & IV \\
\hline Constant & $\begin{array}{c}7.27 \\
(1.30)\end{array}$ & $\begin{array}{c}4.97 \\
(1.85)\end{array}$ & $\begin{array}{c}2.19 \\
(0.87)\end{array}$ & $\begin{array}{c}1.43 \\
(1.07)\end{array}$ \\
\hline Openness & $\begin{array}{c}0.00 \\
(0.16)\end{array}$ & $\begin{array}{c}1.02 \\
(0.48)\end{array}$ & $\begin{array}{c}0.17 \\
(0.09)\end{array}$ & $\begin{array}{c}0.44 \\
(0.23)\end{array}$ \\
\hline Ln Population & $\begin{array}{l}-0.04 \\
(0.05)\end{array}$ & $\begin{array}{c}0.03 \\
(0.06)\end{array}$ & $\begin{array}{c}0.05 \\
(0.03)\end{array}$ & $\begin{array}{c}0.07 \\
(0.03)\end{array}$ \\
\hline In Area & $\begin{array}{c}0.01 \\
(0.04)\end{array}$ & $\begin{array}{c}0.13 \\
(0.07)\end{array}$ & $\begin{array}{l}-0.02 \\
(0.02)\end{array}$ & $\begin{array}{c}0.01 \\
(0.03)\end{array}$ \\
\hline $\operatorname{Ln} s_{k}$ & $\begin{array}{c}0.42 \\
(0.10)\end{array}$ & $\begin{array}{c}0.20 \\
(0.15)\end{array}$ & $\begin{array}{c}0.26 \\
(0.06)\end{array}$ & $\begin{array}{c}0.20 \\
(0.08)\end{array}$ \\
\hline $\operatorname{Ln} s_{h}$ & $\begin{array}{c}0.81 \\
(0.08)\end{array}$ & $\begin{array}{c}0.84 \\
(0.09)\end{array}$ & $\begin{array}{c}0.28 \\
(0.06)\end{array}$ & $\begin{array}{c}0.28 \\
(0.06)\end{array}$ \\
\hline $\operatorname{Ln}(n+g+\delta)$ & $\begin{array}{l}-1.20 \\
(0.42)\end{array}$ & $\begin{array}{l}-1.36 \\
(0.51)\end{array}$ & $\begin{array}{l}-0.31 \\
(0.26)\end{array}$ & $\begin{array}{l}-0.32 \\
(0.27)\end{array}$ \\
\hline $\begin{array}{l}\text { Ln Initial } \\
\text { Inc./Pop. }\end{array}$ & & & $\begin{array}{c}0.69 \\
(0.05)\end{array}$ & $\begin{array}{c}0.71 \\
(0.06)\end{array}$ \\
\hline Sample Size & 98 & 98 & 98 & 98 \\
\hline $\mathbf{R}^{2}$ & 0.82 & 0.75 & 0.94 & 0.93 \\
\hline S.e.e. & 0.48 & 0.57 & 0.28 & 0.30 \\
\hline $\begin{array}{l}\text { First-Stage F } \\
\text { on Excluded } \\
\text { Instruments }\end{array}$ & & 17.15 & & 20.91 \\
\hline
\end{tabular}

The dependent variable is log income per person in 1985. Standard errors are in parentheses. 


\section{APPENDIX}

Basic Data

Actual Constr. Constr.

Tr. Share Tr. Share Tr. Share

Country

Algeria

Angola

Benin

Botswana

Burkina Faso

Burundi

Cameroon

Cape Verde Is

Central Afr. R.

Chad

Comoros

Congo

Dj ibouti

Egypt

Ethiopia

Gabon

Gambia

Ghana

Guinea

Guinea-Bissau

Ivory Coast

Kenya

Lesotho

Liberia

Madagascar

Malawi

Mali

Mauritania

Mauritius

Morocco

Mozambique

Namibia

Niger

Nigeria

Reunion

Rwanda

Senegal

Seychelles

Sierra Leone

Somalia

South Africa

Sudan

Swaz 11 and

Tanzania

Togo

\section{(1985)}

49.66

69.10

76.99

121.28

52.42

30.82

57.67

118.02

65.23

61.43

67.06

112.81

117.06

51.97

34.13

100.18

89.14

21.29

71.80

62.74

78.19

51.69

152.42

79.63

30.99

54.09

73.60

141.56

109.10

58.50

18.38

119.81

51.27

28.53

53.14

30.65

70.63

111.95

19.15

25.64

55.43

21.34

118.71

21.03

105. 52 (Geog.) (Accum.)

13.97

11.51

42.20

24.03

14.10

24.86

15.79

45.11

15.13

12.00

46.77

25.77

70.97

11.75

8.44

30.65

52.20

18.87

23.95

42.24

16.58

12.48

20.66

29.81

9.90

12.67

12.80

23.44

31.11

12.71

11.11

21.31

12.37

8.68

39.92

26.20

19.87

84.98

27.81

14.89

8.90

10.97

56.87

10.97

41.47
12.51

3.85

9.22

8.28

3.50

4.80

6.50

15.99

5.23

2. 39

15.72

9.48

14.09

10.32

3.41

7.31

13.25

8.87

6.53

10.47

6.72

5.94

7.75

9.72

3.56

3.83

3.60

6.41

25.35

9.95

2.41

5.60

3.21

5.22

14.38

4.67

6.38

25.59

6.65

4.37

4.76

5.47

10.40

2.84

13.28
Area $\left(10^{3}\right.$

sq. mi.)

919.595

481.354

43.483

231.800

105.870

10.747

183.569

1.557

241.313

495.755

0.863

132.046

8.958

386.900

472.432

103.346

4.093

92.100

94.926

13. 948

124.502

224.960

11.720

43.000

226.660

45.747

482.077

397.953

0.787

172.413

308.642

317.818

489.206

356.700

0.969

10.169

75.954

0.175

27.700

246.199

471.440

967.491

6.704

364.900

21.925
Pop . (Millions)

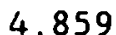

3.512

1.874

0.370

4.150

2.539

3.831

0.120

1.309

1.791

0.181

0.760

0.105

12.719

18.385

0.420

0.358

4.468

2.243

0.425

4.030

7.980

0.743

0.811

4.498

3.180

2.332

0.533

0.577

6.714

7.290

0.380

3. 343

30.743

0.216

3.005

2.758

0.029

1.372

2. 774

11. 240

7.121

0.277

10.266

1.277

Income/

Worker

(1985) 


\begin{tabular}{|c|c|c|c|c|c|c|}
\hline Tunisia & 71.33 & 23.83 & 20.64 & 63.379 & 2.280 & 8783 \\
\hline Uganda & 22.54 & 12.97 & 3.76 & 91.343 & 6.236 & 1224 \\
\hline Zaire & 53.15 & 8.97 & 3.82 & 905.365 & 12.321 & 1136 \\
\hline Zambia & 76.96 & 13.81 & 5.65 & 290.586 & 2.274 & 2399 \\
\hline Zimbabwe & 56.40 & 11.27 & 6.08 & 150.699 & 3.135 & 3261 \\
\hline Bahamas & 124.11 & 38.03 & 22.54 & 5.382 & 0.097 & 29815 \\
\hline Barbados & 130.30 & 56.10 & 38.63 & 0.166 & 0.127 & 12212 \\
\hline Belize & 183.27 & 87.48 & 31.10 & 8.866 & 0.049 & 8487 \\
\hline Canada & 54.48 & 4.97 & 8.05 & 3851.809 & 12.595 & 31147 \\
\hline Costa Rica & 63.19 & 23.37 & 15.07 & 19.652 & 0.920 & 9148 \\
\hline Dominica & 103.09 & 75.08 & 38.44 & 0.305 & 0.030 & 6163 \\
\hline Dom. Rep. & 64.24 & 22.37 & 13.75 & 18.704 & 1.912 & 7082 \\
\hline El Salvador & 52.21 & 28.91 & 12.98 & 8.260 & 1.564 & 5547 \\
\hline Grenada & 120.63 & 81.25 & 43.89 & 0.133 & 0.039 & 4502 \\
\hline Guatemala & 24.94 & 22.04 & 9.16 & 42.042 & 2.262 & 7358 \\
\hline Haiti & 38.44 & 20.44 & 9.52 & 10.714 & 2.514 & 2125 \\
\hline Honduras & 54.15 & 27.58 & 10.56 & 43.277 & 1.307 & 4652 \\
\hline Jamaica & 131.89 & 22.19 & 25.11 & 4.411 & 1.059 & 4726 \\
\hline Mexico & 25.74 & 4.52 & 5.55 & 761.600 & 24.669 & 17036 \\
\hline Nicaragua & 36.60 & 23.46 & 11.28 & 50.180 & 0.980 & 5900 \\
\hline Panama & 70.96 & 23.56 & 18.17 & 29.761 & 0.760 & 10039 \\
\hline Puerto Rico & 136.74 & 22.75 & 19.43 & 3.515 & 1.101 & 21842 \\
\hline St. Lucia & 165.77 & 68.83 & 38.50 & 0.238 & 0.057 & 5317 \\
\hline St. Vin. \& Gre. & 152.17 & 79.41 & 42.77 & 0.150 & 0.042 & 5796 \\
\hline Trin. \& Tobago & 61.90 & 30.33 & 25.92 & 1.980 & 0.441 & 25529 \\
\hline United States & 18.01 & 2.56 & 5.22 & 3540.939 & 117.362 & 33783 \\
\hline Argentina & 17.10 & 5.60 & 5.97 & 1072.067 & 10.798 & 14955 \\
\hline Bolivia & 30.27 & 8.06 & 7.79 & 424.162 & 1.978 & 5623 \\
\hline Brazil & 19.34 & 3.03 & 3.31 & 3286.470 & 49.609 & 10977 \\
\hline Chile & 53.85 & 7.25 & 7.70 & 292.132 & 4.303 & 9768 \\
\hline Colombia & 26.33 & 7.54 & 7.43 & 439.735 & 9.433 & 9276 \\
\hline Ecuador & 47.63 & 11.42 & 10.76 & 109.484 & 2.820 & 9615 \\
\hline Guyana & 109.95 & 25.92 & 15.98 & 83.000 & 0.280 & 3573 \\
\hline Paraguay & 49.58 & 10.43 & 7.80 & 157.047 & 1.226 & 6241 \\
\hline Peru & 39.42 & 7.03 & 7.56 & 496.222 & 6.107 & 8141 \\
\hline Suriname & 82.99 & 30.96 & 17.20 & 63.251 & 0.124 & 10883 \\
\hline Uruguay & 47.86 & 17.07 & 15.52 & 68.040 & 1.169 & 10216 \\
\hline Venezuela & 40.76 & 8.94 & 7.82 & 352.143 & 5.789 & 18362 \\
\hline Bahrain & 188.70 & 71.82 & 53.73 & 0.240 & 0.178 & 22840 \\
\hline Bangladesh & 25.78 & 10.31 & 8.55 & 55.598 & 27.684 & 4265 \\
\hline Bhutan & 62.54 & 37.74 & 28.90 & 17.954 & 0.575 & 1504 \\
\hline China & 19.44 & 2.30 & 4.49 & 3689.631 & 612.363 & 2166 \\
\hline Hong Kong & 209.52 & 35.88 & 48.43 & 0.398 & 3.516 & 16447 \\
\hline India & 15.04 & 3.29 & 4.68 & 1229.737 & 295.478 & 2719 \\
\hline Indonesia & 42.66 & 4.47 & 5.01 & 735.268 & 62.136 & 4332 \\
\hline Iran & 15.20 & 10.06 & 10.96 & 636.293 & 13.540 & 13847 \\
\hline Iraq & 49.22 & 19.14 & 16.64 & 169.235 & 4.105 & 15855 \\
\hline Israel & 85.80 & 54.17 & 41.99 & 8.020 & 1.602 & 21953 \\
\hline Japan & 25.54 & 5.47 & 14.41 & 143.574 & 75.526 & 18820 \\
\hline Jordan & 113.50 & 68.18 & 39.46 & 37.297 & 0.601 & 15655 \\
\hline Korea, Rep. & 67.86 & 14.36 & 28.18 & 38.031 & 16.608 & 10361 \\
\hline Kuwait & 96.45 & 42.55 & 30.34 & 6.880 & 0.640 & 35065 \\
\hline Laos & 13.80 & 27.32 & 19.20 & 91.429 & 1.758 & 2739 \\
\hline Malaysia & 104.69 & 16.82 & 14.07 & 128.328 & 6.217 & 10458 \\
\hline
\end{tabular}




\begin{tabular}{|c|c|c|c|c|c|c|}
\hline Mongolia & 82.72 & 13.52 & 16.67 & 604.829 & 0.894 & 3966 \\
\hline Myanmar & 13.16 & 10.74 & 8.14 & 261.220 & 16.613 & 1332 \\
\hline Nepal & 31.29 & 13.26 & 9.23 & 54.463 & 6.958 & 2244 \\
\hline Oman & 87.06 & 34.19 & 19.12 & 82.030 & 0.368 & 31609 \\
\hline Pakistan & 34.00 & 8.04 & 6.54 & 310.400 & 28.567 & 4249 \\
\hline Philippines & 45.84 & 8.84 & 14.64 & 115.830 & 19.945 & 4229 \\
\hline Qatar & 80.94 & 69.56 & 35.90 & 4.412 & 0.166 & 36646 \\
\hline Saudi Arabia & 79.97 & 14.98 & 10.60 & 865.000 & 3.652 & 28180 \\
\hline Singapore & 318.07 & 48.90 & 56.45 & 0.220 & 1.189 & 17986 \\
\hline Sri Lanka & 62.93 & 13.94 & 15.08 & 25.332 & 5.786 & 5597 \\
\hline Syria & 37.23 & 37.44 & 25.72 & 71.498 & 2.556 & 17166 \\
\hline Taiwan & 94.62 & 17.92 & 27.19 & 13.895 & 8.262 & 12701 \\
\hline Thailand & 51.20 & 9.45 & 9.44 & 198.455 & 26.793 & 4751 \\
\hline U. A. Emirates & 89.66 & 33.42 & 20.80 & 32.000 & 0.694 & 38190 \\
\hline Yemen & 49.34 & 16.83 & 12.47 & 128.560 & 2.369 & 6425 \\
\hline Austria & 81.27 & 36.64 & 56.95 & 32.375 & 3.528 & 23837 \\
\hline Belgium & 151.34 & 52.46 & 77.66 & 11.781 & 4.071 & 27325 \\
\hline Bulgaria & 85.99 & 31.12 & 45.96 & 42.823 & 4.417 & 9662 \\
\hline Cyprus & 107.57 & 54.39 & 57.94 & 3.572 & 0.310 & 13918 \\
\hline Czechoslovakia & 69.45 & 21.07 & 39.58 & 49.383 & 8.137 & 7467 \\
\hline Denmark & 72.99 & 30.89 & 56.68 & 16.631 & 2.780 & 23861 \\
\hline Finland & 57.50 & 21.64 & 41.09 & 130.119 & 2.493 & 23700 \\
\hline France & 47.17 & 15.26 & 28.94 & 211.208 & 24.882 & 27064 \\
\hline Germany, West & 61.52 & 18.47 & 34.46 & 96.010 & 28.085 & 27252 \\
\hline Greece & 53.97 & 27.01 & 38.98 & 50.961 & 3.800 & 16270 \\
\hline Hungary & 82.32 & 26.92 & 46.20 & 35.920 & 5.195 & 10827 \\
\hline Iceland & 81.83 & 33.08 & 32.80 & 39.709 & 0.127 & 23256 \\
\hline Ireland & 118.84 & 33.85 & 54.49 & 26.600 & 1.342 & 19197 \\
\hline Italy & 46.06 & 13.97 & 26.92 & 116.500 & 22.714 & 27189 \\
\hline Luxembourg & 211.94 & 281.29 & 235.01 & 0.999 & 0.157 & 30782 \\
\hline Malta & 160.86 & 98.14 & 127.57 & 0.122 & 0.119 & 15380 \\
\hline Netherlands & 118.76 & 35.84 & 63.30 & 16.041 & 5.855 & 28563 \\
\hline Norway & 86.00 & 23.54 & 41.23 & 125.049 & 2.043 & 28749 \\
\hline Poland & 35.07 & 13.84 & 28.80 & 120.728 & 19.235 & 8079 \\
\hline Portugal & 77.95 & 18.78 & 27.32 & 35.550 & 4.540 & 11343 \\
\hline Romania & 41.62 & 18.80 & 32.10 & 91.699 & 11.275 & 4021 \\
\hline Spain & 43.51 & 12.38 & 21.43 & 194.885 & 13.732 & 21169 \\
\hline Sweden & 69.02 & 18.22 & 32.41 & 173.800 & 4.238 & 26504 \\
\hline Switzerland & 77.69 & 32.57 & 48.85 & 15.941 & 3.222 & 29848 \\
\hline Turkey & 44.40 & 11.26 & 15.37 & 300.947 & 21.829 & 7091 \\
\hline United Kingdom & 56.87 & 13.47 & 32.81 & 94.247 & 27.684 & 22981 \\
\hline U.S.S.R. & 18.28 & 3.68 & 7.71 & 8600.387 & 142.801 & 13700 \\
\hline Yugos lavia & 57.88 & 25.82 & 42.93 & 39.449 & 10.475 & 11417 \\
\hline Australia & 35.28 & 4.07 & 5.14 & 2966.150 & 7.391 & 28960 \\
\hline Fiji & 89.13 & 18.56 & 15.72 & 7.078 & 0.232 & 9840 \\
\hline New Zealand & 65.25 & 8.19 & 9.98 & 103.884 & 1.438 & 26039 \\
\hline Papua N. Guinea & 94.52 & 10.17 & 5.80 & 178.704 & 1.660 & 3374 \\
\hline Solomon Is. & 123.60 & 25.12 & 17.68 & 10.954 & 0.088 & 5109 \\
\hline Tonga & 102.25 & 43.40 & 31.87 & 0.288 & 0.030 & 6022 \\
\hline Vanuatu & 123.33 & 30.86 & 19.87 & 4.707 & 0.042 & 5707 \\
\hline Western Samoa & 92.17 & 32.77 & 24.47 & 1.093 & 0.050 & 5388 \\
\hline
\end{tabular}




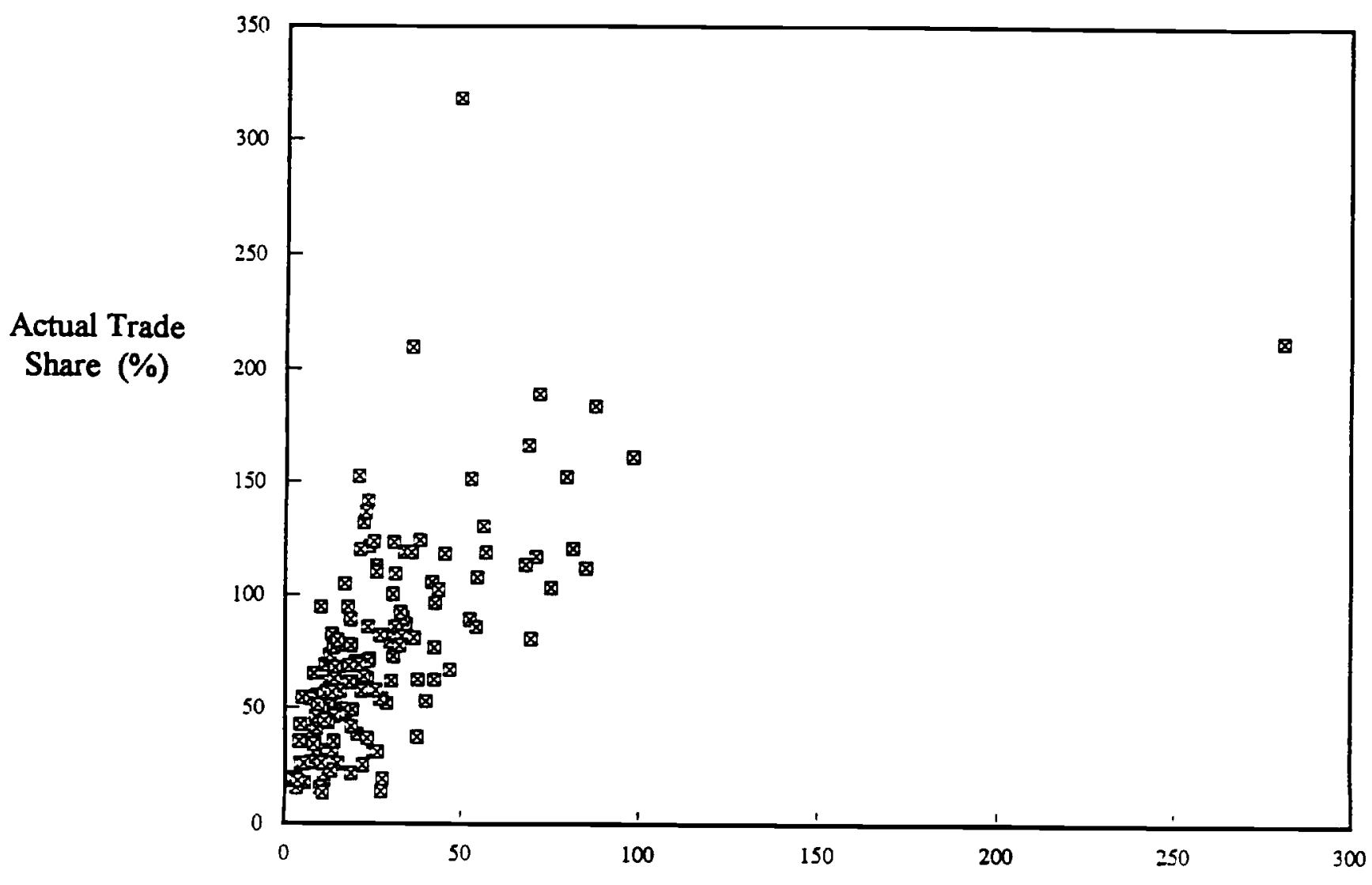

Constructed Trade Share (\%)

Figure 1. Actual Versus Constructed Openness (Pure Geography Approach) 


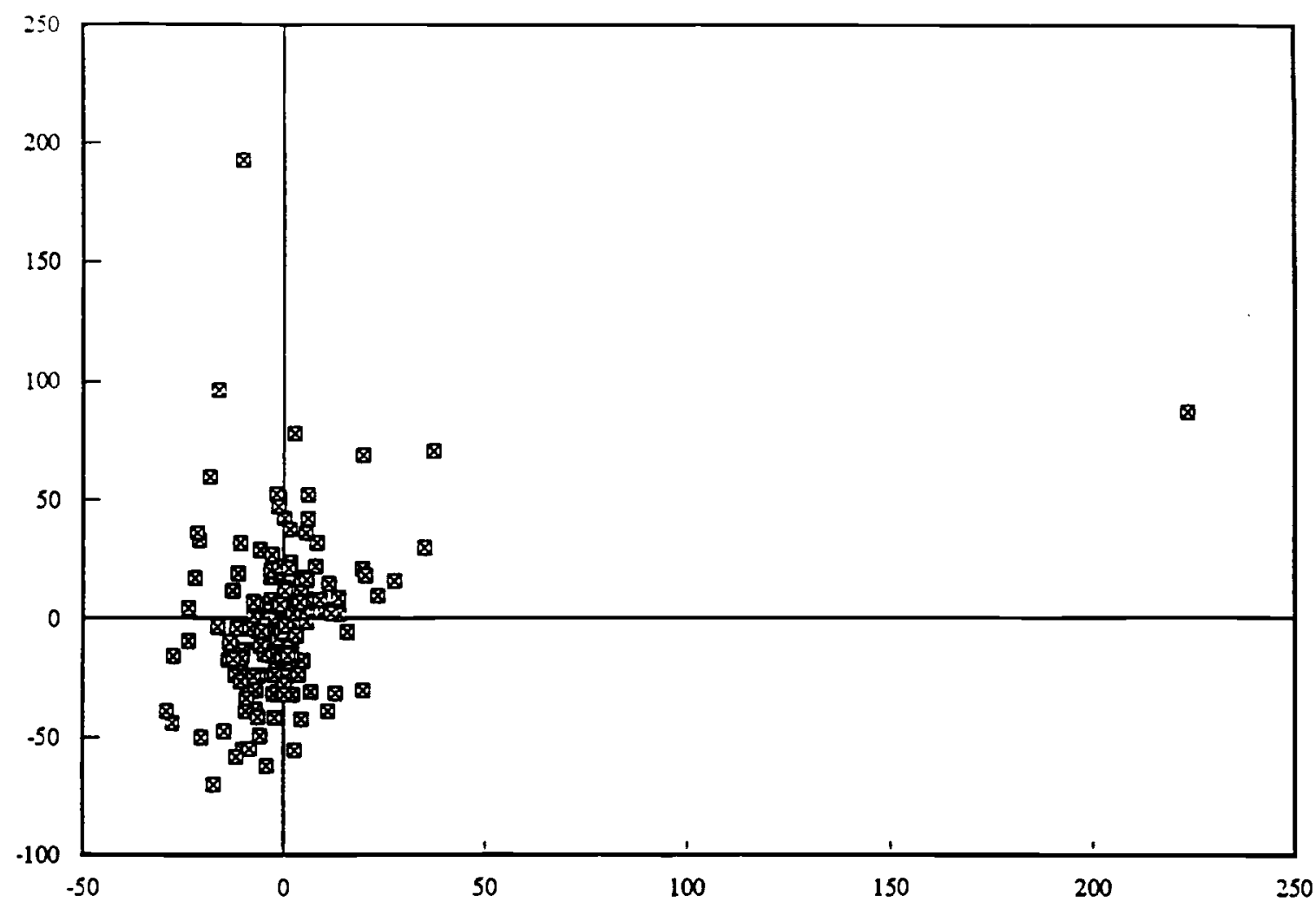

A. Full Sample

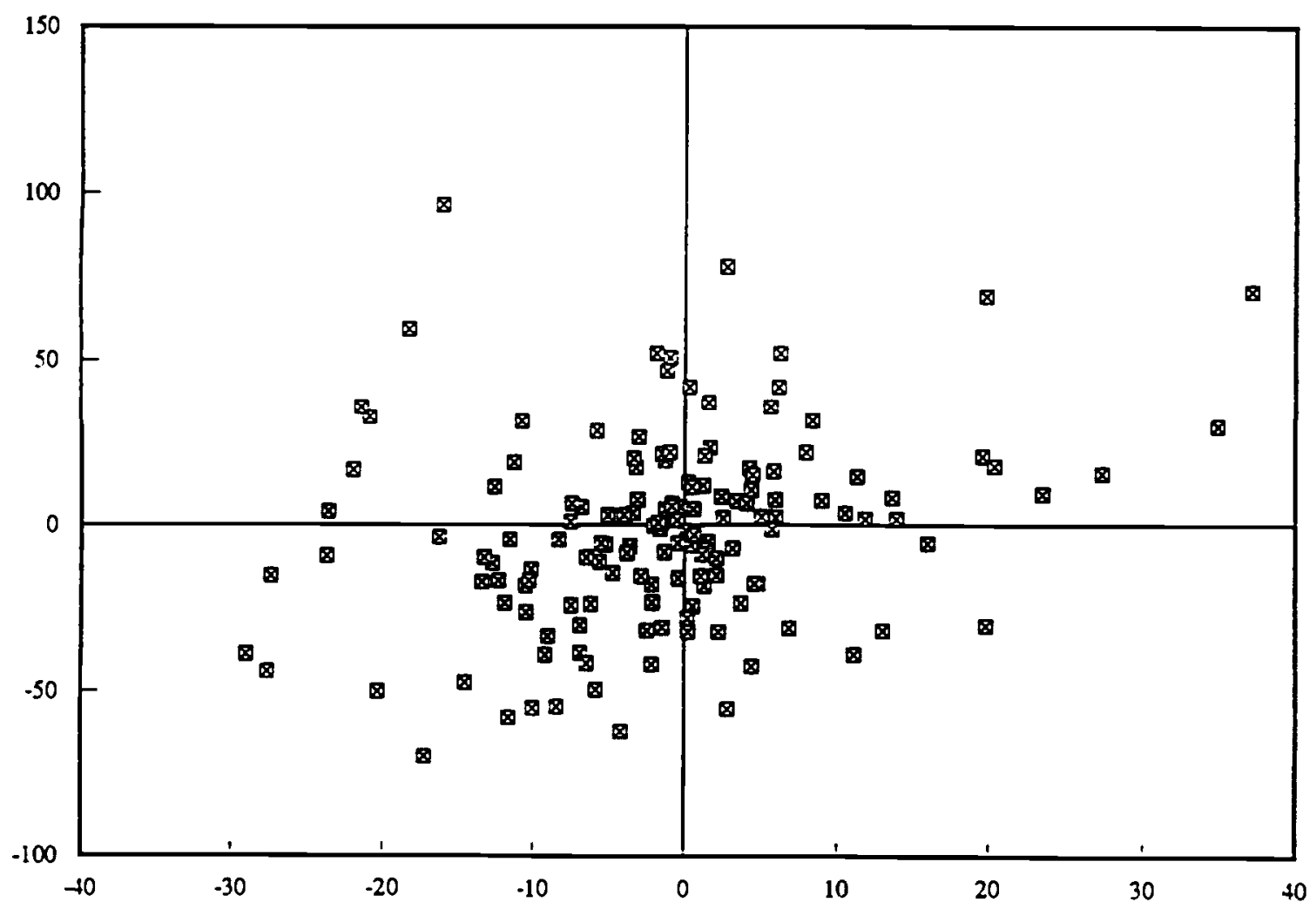

B. Luxembourg and Singapore Omitted

Figure 2. Partial Association between Actual and Constructed Openness (Pure Geography Approach) 


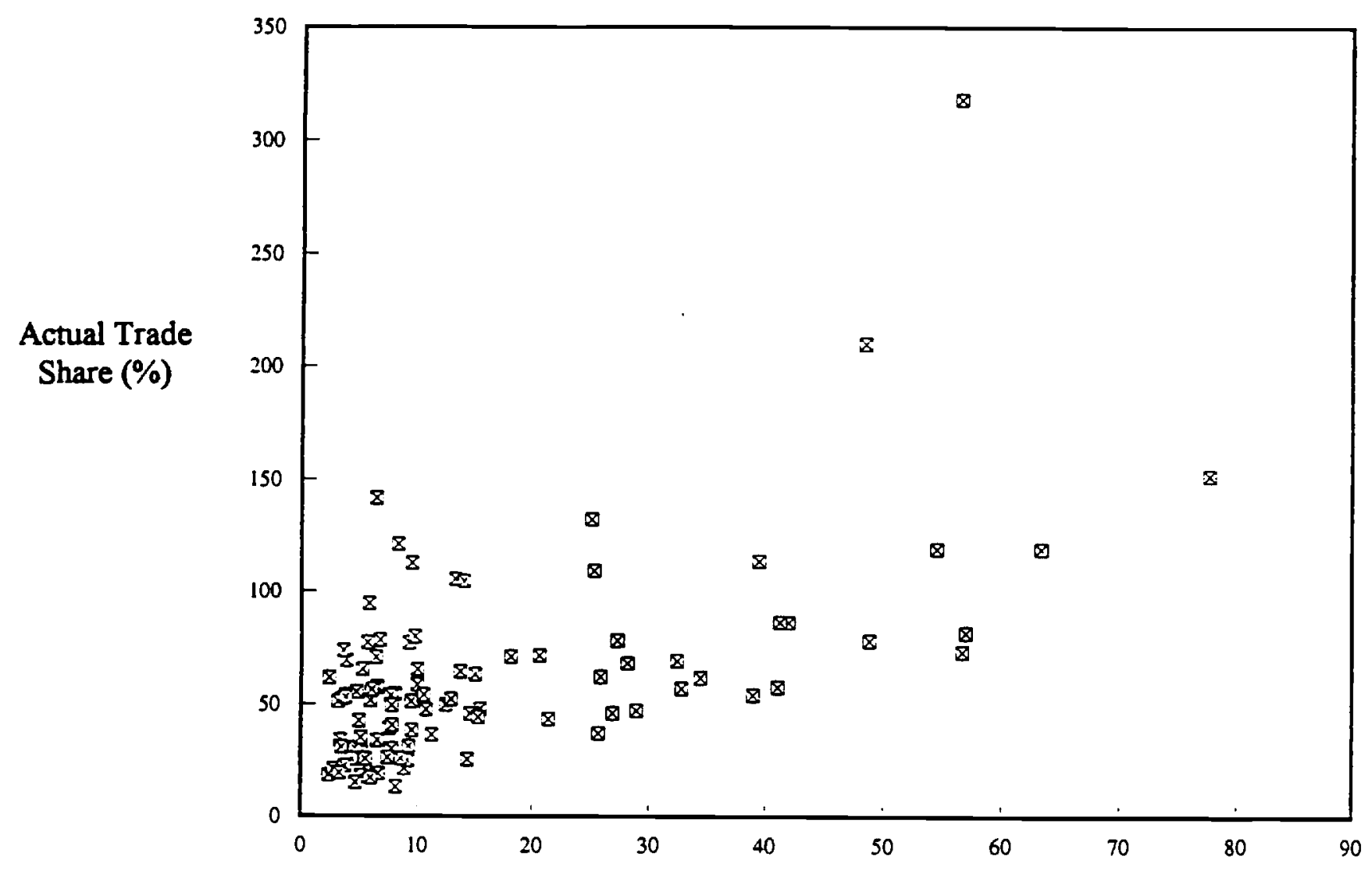

Constructed Trade Share (\%)

Figure 3. Actual Versus Constructed Openness (Factor Accumulation Approach) 


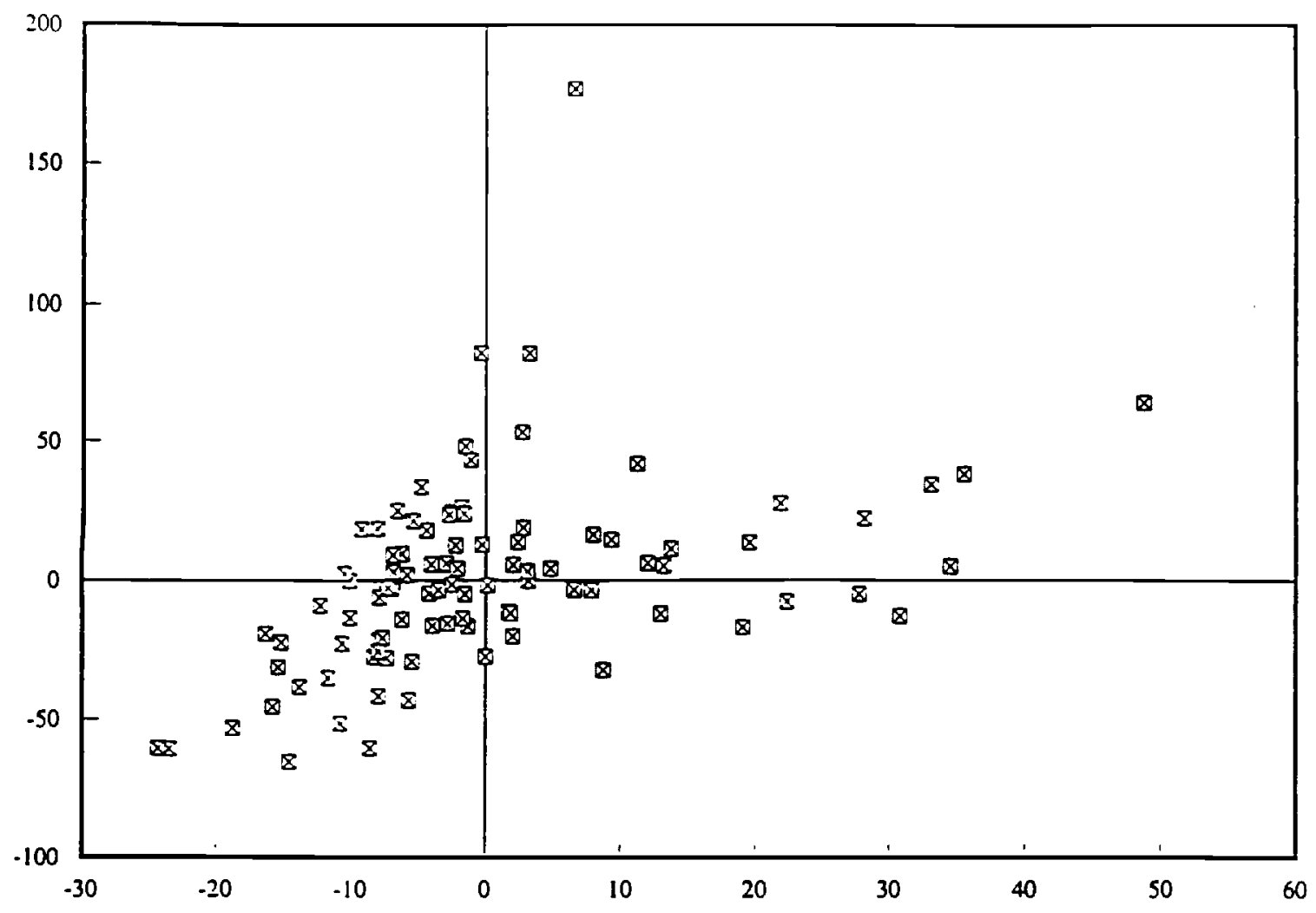

A. Full Sample

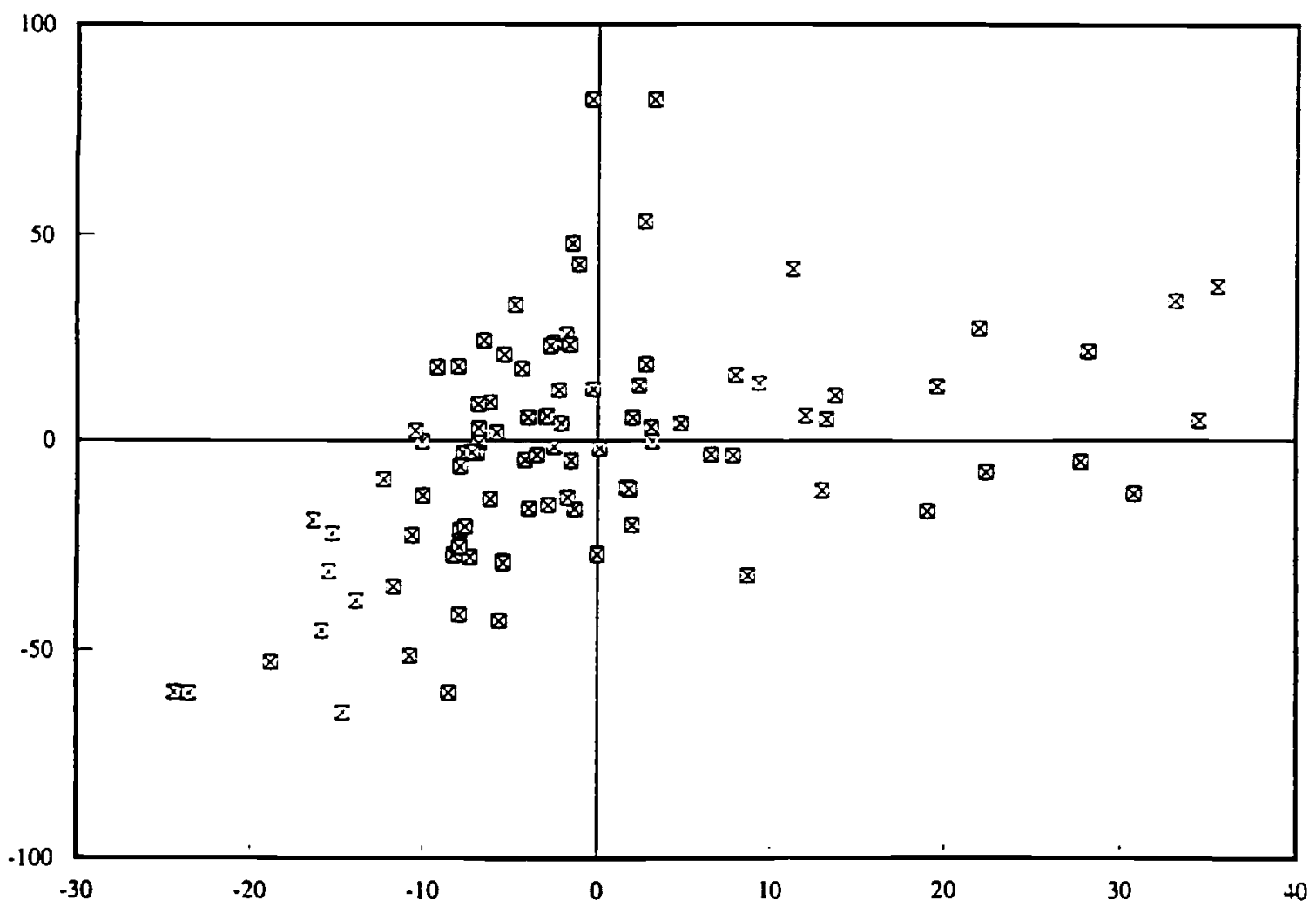

B. Singapore and Belgium Omitted

Figure 4. Partial Association between Actual and Constructed Openness (Factor Accumulation Approach) 